UNITED STATES DEPARTMENT OF THE INTERIOR

GEOLOGICAL SURVEY

\author{
Density, porosity, and magnetic properties \\ of rock specimens from southwestern Arizona
}

by

Douglas P. Klein

and

Gordon R. Johnson

Open-File report $83-808$

This report is preliminary and has not been reviewed for conformity with U.S. Geological Survey editorial standards and stratigraphic nomenclature. The use of brand names is for descriptive purposes and does not imply endorsement by the U.S. Geological Survey. 


\section{Contents}

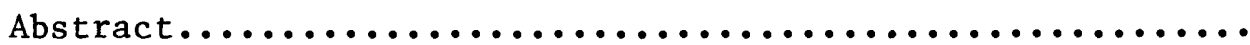

Introduction.

Data...

Discussion.

Summary

Acknowledgements

References..................................

Appendix A -- List of abbreviations for rock types and geologic map units used in this report........

Appendix B -- Tabulation of rock specimen locations and petrophysical measurements...............

Appendix C -- Tabulation of petrographic identification of selected rock specimens.................

Tables

Table 1 -- Logarithmic mean values and range for measured magnetic properties, $\mathrm{S}$ and $\mathrm{M} . \ldots \ldots \ldots \ldots \ldots \ldots \ldots$

Table 2 -- Logarithmic mean values and range for computed magnetic properties, $Q$ and $s_{a} \ldots \ldots \ldots \ldots \ldots \ldots \ldots$

Table 3 -- Mean values and range for measured density properties............................

Table 4 -- Condensed summary of average magnetic and density properties for rock-samples measurements in

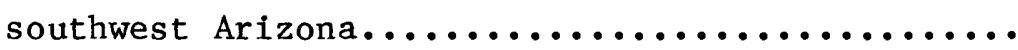

Figures

Fig. 1 -- Map showing area of rock sampling in southwest

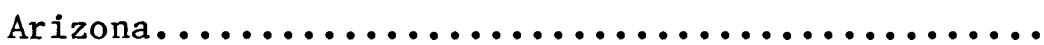




\section{Abstract}

Petrophysical data on 364 rock specimens from southwest Arizona are tabulated and summarized by major rock suites for that part of southwest Arizona covered by the Ajo $1^{\circ} \times 2^{\circ}$ quadrangle and the Papago Indian Reservation. Data for 202 of these specimens are new and previous1y unreported. The tabulation also contains data from theses by B. A. Hargan and B. T. May, University of Arizona. 


\title{
Density, porosity, and magnetic properties of rock specimens from southwestern Arizona
}

by

\author{
Douglas P. Klein \\ and \\ Gordon R. Johnson

\section{INTRODUCTION}

This report presents data obtained from petrophysical examination of 202 rock samples collected in conjunction with geophysical field work in southwestern Arizona (fig. 1). Many of the sample sites are on the Luke Air Force Gunnery and Bombing Range which ordinarily has limited access. Physical properties measured were density, porosity, magnetic susceptibility, and natural remanent magnetization. Rock samples were taken as time permitted during the course of gravity surveys which determined the distribution of sample sites. Petrophysical analysis was also performed on a time available basis, thus complete analyses are not available for all rocks.

The new data are supplemented by data from 118 sample locations tabulated in the University of Arizona Gravity Data Base bedrock file. These data were provided to the U.S. Geological Survey under terms of a research grant (see Hargan, 1978) awarded to the University by the U.S. Geological Survey. Also included in the present compilation are data from 44 samples analyzed for magnetic properties and reported in a thesis by B. T. May (1968). There also exists a summary of rock-density data in the vicinity of lat. $32^{\circ} \mathrm{N}$, long. $112^{\circ} \mathrm{W}$ by Greenes (1980), and a generalized discussion and tabulation of petrophysical data of mineralized terrane in the Southwest by Brant (1966). Neither of the latter two data sets are included here.

\section{DATA}

Appendix B tabulates the locations, rock identifications, and petrophysical measurements for all samples of this report. The tabulation is a computer listing that has been sorted alphabetically first by rock type (the abbreviations used are listed in appendix A) and second by physiographic locality. Sample locations except for those extracted from May's thesis (1968) are shown on plate 1. May's data were collected in a small area surrounding the Ajo porphyry copper deposit and individual sample locations cannot be clearly shown at the scale of 1:250,000. The source of data is listed in appendix B as: 1, USGS data; 2, University of Arizona data; 3, May's data.

Sampling for the USGS data consisted of collecting one or more hand-sized specimens from each locality. The specimens were broken from rock-outcrops without determining orientation. These specimens were subsequently cored to produce, on the average, about five cylindrical samples from each locality for analysis. Each core was one-inch $(25 \mathrm{~mm})$ in diameter and 1-2 inches (25-50 $\mathrm{mm}$ ) in length. Appendix B lists the average of results of laboratory 


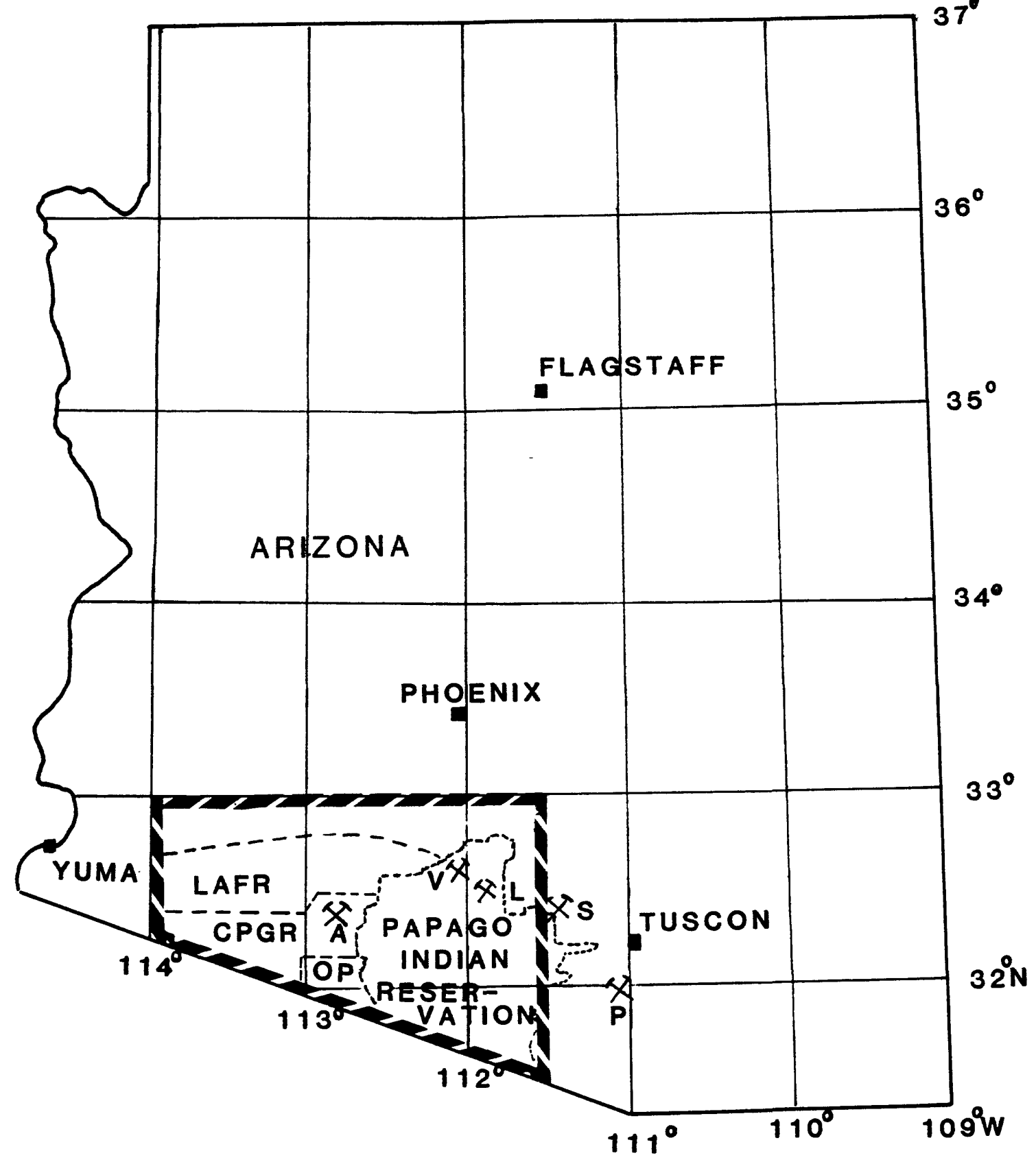

Fig. 1 -- Map showing area of rock sampling in southwest Arizona. The hachured border shows the area of plate 1, and includes the Ajo 1-degree by 2-degree quadrangle (1at. $32^{\circ}-33^{\circ}$ N., long. $112^{\circ}-114^{\circ} \mathrm{W}$ ), the Papago Indian Reservation, Luke Air Force Bombing and Gunnery Range (LAFR), Cabeza-Prieta Game Range (CPGR) and Organ Pipe Cactus Nationa 1 Monument (OP). Porphyry copper mineral deposits shown are Ajo (A), Vekol (V), Lakeshore (L), Silver Bell (S) and Pima-Mission ( $P$ ). 
measurements on samples from each locality. The measurement techniques followed procedures documented by Hunt and others (1979) and are briefly described below. Sample identification for rock type was based largely on macroscopic examination of the hand specimens prior to coring. A small percentage of the cores were thin-sectioned and subjected to petrographic classification. Some of the rock-types listed are highly general, for instance "volcaniclastic rock". Three rocks were not identified and are listed as unknown. The geologic unit (Wilson and others, 1969, May, 1969, Kahle and others, 1978) for each sample locality is shown in Appendix B, but is of limited value, except for the area around Ajo, inasmuch as formation ages and classifications are often questionable in this part of Arizona. New geologic mapping is presently underway.

Density measurements were obtained on the cylindrical samples using the buoyancy or Archimedes' method. The samples were dried in an oven at $105^{\circ} \mathrm{C}$ and then weighed $\left(W_{d}\right)$ to an accuracy of $0.1 \mathrm{mg}$. The samples were next vacuumsaturated with distilled water and subsequently weighed both in air and submerged but suspended in a water bath. From these data dry bulk densities (D) were calculated as follows:

$$
D=\frac{W_{d}}{W_{s}-W_{s p}}
$$

where $W_{S}$ and $W_{S p}$ are respectively the water-saturated weights in air and suspended in water. The density of distilled water at room temperature was assumed to be one $\mathrm{g} / \mathrm{cm}^{3}$.

relation

Porosity ( $P$ ), in percent, were calculated from the above data by the

$$
\mathrm{P}=\left(\frac{\mathrm{W}_{\mathrm{s}}-\mathrm{W}_{\mathrm{d}}}{\mathrm{W}_{\mathrm{s}}-\mathrm{W}_{\mathrm{sp}}}\right) 100 .
$$

The above equation expresses a measure of the pores that are saturable by water. Total porosity can only be obtained by pulverizing the rock material to a degree sufficient to eliminate all occluded pores.

Magnetic susceptibilities were measured using a direct-reading mode1 3101 Bison bridge, an instrument patterned after a design originally described by Mooney (1953). A correction factor was applied to the readings because the cylinder lengths were usually less than the depth of the sample holder.

Natural remanent magnetization was determined from measurements made with a Schonstedt spinner magnetometer using either a three- or six-spin technique. Six-spin measurements are usually required for those samples whose remanent intensity falls below $10^{-4} \mathrm{emu} / \mathrm{cm}^{3}$ (Hunt and others, 1979). In a six-spin measurement the core sample is alternately spun in opposite directions at each of the three axial orientations. Prior to measurement each sample was reduced in length to conform to the $25 \times 25 \mathrm{~mm}$ size required for use in the Schonstedt magnetometer. Because the original orientation of the samples was not known only the remanent magnetic intensity determined as the absolute value of the vector sum of the components is reported.

The International system of units (SI) is used in this report. Inasmuch as cgs-emu units are commonly reported for petrophysical properties, the conversions between systems for the quantities used in this report are 
summarized below. The reader is referred to Sheriff (1973, p. 134) for a table of conversions for magnetic quantities, and to U.S. National Bureau of Standards (1974) and the American Society for Testing and Materials (1976) for a description of the SI system.

Volume percent porosity and specific gravity (numerically equivalent to cgs density) are constant between systems. SI density $\left(\mathrm{kg} / \mathrm{m}^{3}\right)$ is related to cgs density $\left(\mathrm{g} / \mathrm{cm}^{3}\right)$ by:

$$
10^{-3} \mathrm{~kg} / \mathrm{m}^{3}=1 \mathrm{~g} / \mathrm{cm}^{3}
$$

Remanent magnetization, $M$, in SI units of $\mathrm{amp} / \mathrm{m}$ is related to cgs-emu units of oersted, or $\mathrm{emu} / \mathrm{cm}^{3}$, by:

$$
10^{-3} \mathrm{amp} / \mathrm{m}(\mathrm{SI})=1 \text { oersted }\left(\mathrm{cgs}, \mathrm{emu} / \mathrm{cm}^{3}\right)
$$

Note that magnetization has the units of magnetic field, $H$, which in the cgsemu system is numerically equivalent to magnetic induction $\underline{B}$ (gauss, $\underline{B}=\mu_{0} \mathrm{H}$ ) because the magnetic permeability in free space $\left(\mu_{0}\right)$ is defined as 1 gauss/oersted. This equivalence is not present in the SI system because $\mu_{0}=$ $4 \pi \times 10^{-7}$ testa-m/amp.

Magnetic susceptibility, $\mathrm{S}$, is a dimensionless ratio of induced magnetization to external magnetic field $\underline{H}$. The relationships between systems is given by:

$$
4 \pi \quad \text { SI }=1 \text { cgs-emu }
$$

The Koenigsberger ratio is also a dimensionless ratio of remanent magnetization, $\mathrm{M}$, to induced magnetization, SH. This ratio is invariant between systems. The magnetic field, $\mathrm{H}$, is related between systems by

$$
\frac{10}{4 \pi}^{3} \mathrm{amp} / \mathrm{m}(\mathrm{SI})=1 \text { gauss }(\mathrm{cgs}-\mathrm{emu}) \text {. }
$$

A typical value for Earth's total magnetic intensity in southern Arizona is $79.6 \mathrm{amp} / \mathrm{m}$, equivalent to 0.5 gauss $(50,000$ gamma).

\section{DISCUSSION}

Tables 1 - 3 summarize the measurements according to the major rock suites represented. Tables 1 and 2 show the logarithmic-mean values and ranges for magnetic properties; table 3 shows the linear mean values and ranges for density and porosity. Range for each quantity is expressed as the limits within which 80-percent of the data fall, centered on the median. Query marks on the lower range of magnetic susceptibility (Table 1) means that the minimum value was less than the resolution of measurement.

The Koenigsberger ratio, Q, andapparent susceptibility, $S_{\text {(Table 2) }}$ are computed quantities (Nagata, 1969). The Koenigsberger ratio is the ratio of the amplitudes of remanent magnetization to induced magnetization that is given as:

$$
\mathrm{Q}=\frac{\mathrm{M}}{\mathrm{SH}}
$$


Table 1 -- Logarithmic mean values for measured magnetic properties $S$ and $M$. The number of samples available for each quantity is given by $\mathrm{n}$. Rock-type abbreviations are listed in appendix B. Ranges are given as 80-percentile limits centered on the median. Queries on the low end of the susceptibility range indicate the sample had magnetization below the resolution of measurement ( $1.26 \times 10^{-4} \mathrm{SI}$, or $\left.0.1 \times 10^{-5} \mathrm{emu}\right)$.

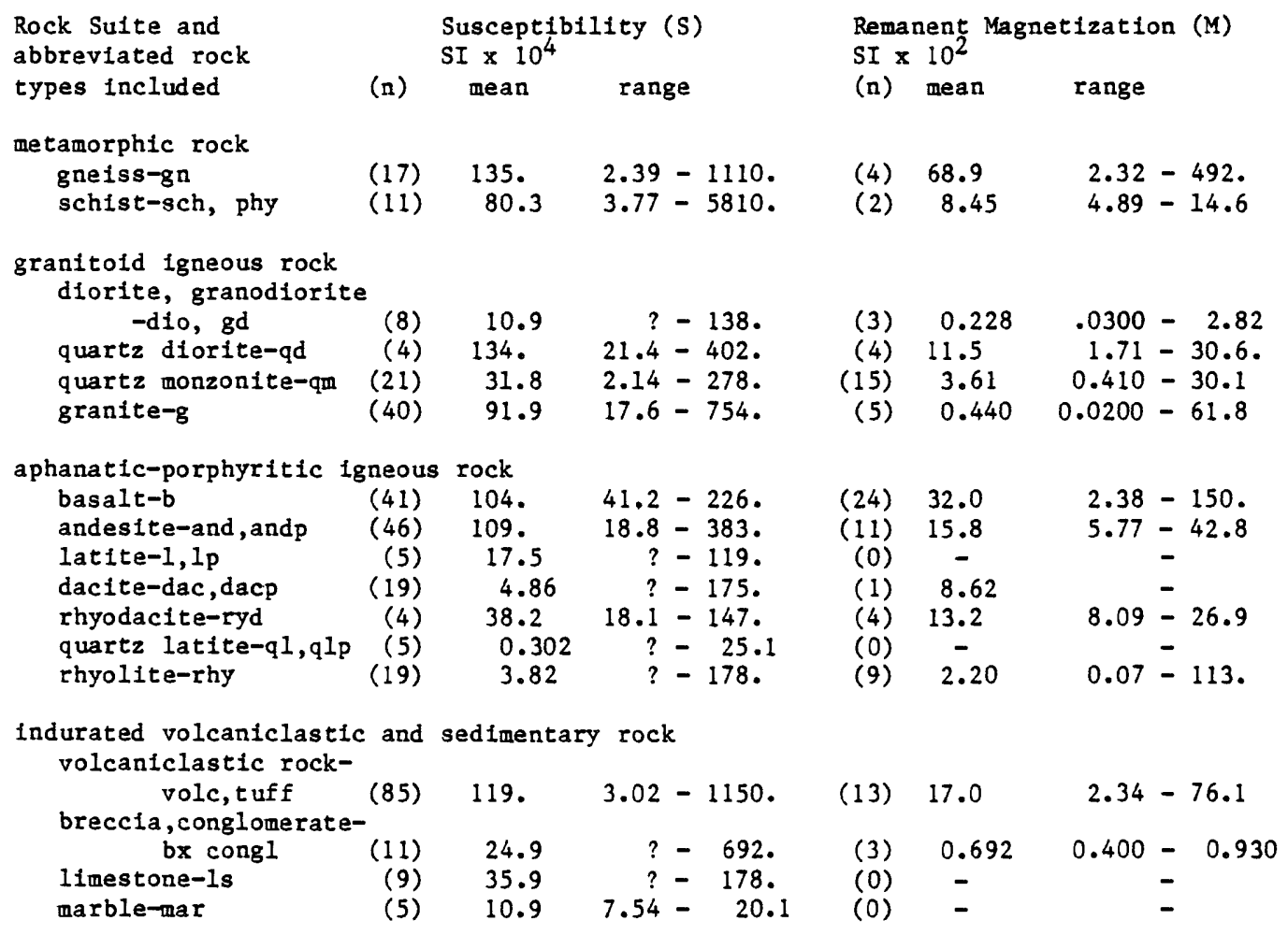


Table 2 -- Logarithmic mean values for computed magnetic properties $Q$ and $S$. The number of samples available for each ${ }^{\text {a }}$ quantity is given by $\mathrm{n}$. Rock-type abbreviations are listed in appendix B. Ranges are given as 80-percentile limits centered on the median.

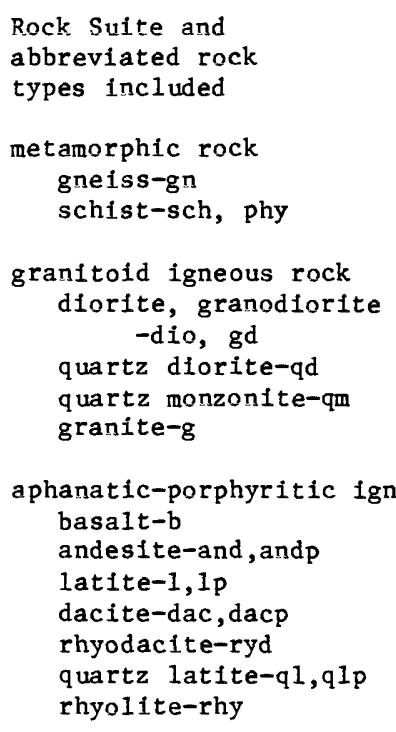

\section{Koenigsberger's \\ Ratio (Q) \\ dimensionless}

(n)

(4) $\quad 3.74 \quad .146-518 . \quad 371: \quad 45.7-1239.46 .4$

(2) $\quad 0.431 \quad .0570-3.26 \quad 105 . \quad 16.1-680.49 .2$

indurated volcaniclastic and sedimentary rock volcaniclastic rockvolc, tuff breccia, conglomerate-
bx congl limestone-1s marble-mar

0.0295
0.215
0.199
0.0453

$.0100-0.0514$
$0.0278-3.60$
$0.0479-1.25$
$0.00631-0.794$

$20.1^{*}$
212.
80.9
$28.3^{*}$

$1.58-145.19 .4$ $98.3-443.134$. 0.810 $\begin{array}{ll}0.810 & 0.0964-4.22 \\ 0.831 & 0.299-1.96\end{array}$

$-$

2.69

.865

$-$

$\overline{1.10}$

-

220.

$92.7-586.99 .2$

$\begin{array}{ccc}- & - & - \\ 29.7 & - & 8.04\end{array}$

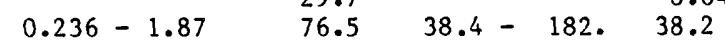

$0.410-32.7$

$\overline{13.2} 1.43-386 . \quad 5.04$ 
Table 3 -- Mean values and range for density properties. The number of sample measurements for $D$ and $P$ is given by $n$. Ranges are given as 80-percentile limits centered on the median. Wet bulk density is a computed quantity (see text). See appendix B for rock-type abbreviations.

Rock Suite and abbreviated rock types included

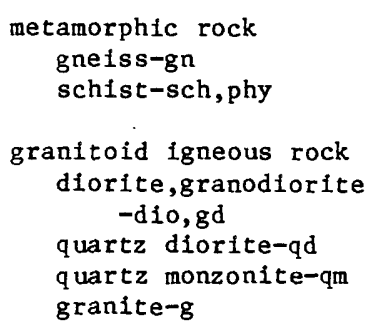

5.9

1.5

2.3-12.

2.65

2.9

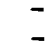

$1.0-7.3$

2.65

2.69

\subsection{0-2.88}

$2.21-2.77$

(26)

(23)

15.

$6.6-27$
$1.5-18$

2.54

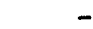

$2.22-2.32$

8.0

-

9.5-14.

2.49

11.

2. $6-36$.

2.38

2.03-2.66

(7)

16.

indurated volcaniclastic and sedimentary rock

$$
\begin{gathered}
\text { volcaniclastic rock- } \\
\text { volc, tuff }
\end{gathered}
$$

(5)

breccta, conglomeratebr cong1

$\begin{array}{lll}\text { (56) } & 2.72 & 2.57-2.92 \\ & & \\ \text { (6) } & 2.66 & 2.54-2.78 \\ \text { (7) } & 2.64 & 2.61-2.69 \\ \text { (5) } & 2.70 & 2.63-2.87\end{array}$

limestone-1s

(5) 2.70

$2.63-2.87$

(6)

$9.92 .4-17$.

2.76

(7) $\quad 1.3 \quad 0.22-3.4 \quad 2.65$

(5) $1.7 \quad 0.33-2.9 \quad 2.71$


The value of $\mathrm{H}$ used in the calculation was $39.8 \mathrm{amp} / \mathrm{m}$ ( 0.5 oersted) equivalent to $50,000 \mathrm{nT}$ (gammas). Apparent susceptibility is calculated as

$$
\mathrm{S}_{\mathrm{a}}=\mathrm{S}(1+\mathrm{Q})
$$

The $Q$ value indicates the relative importance of remanent magnetization compared to the induced magnetization; a low $Q$ suggests that one may neglect remanent magnetization for interpretation. If the $Q$ value approaches 1 or is greater than 1 , some difficulties may be expected in modelling the magnetic field (Strangway, 1967). If the direction of $M$ can be ascertained to be roughly parallel or antiparallel to $\underline{H}, S_{a}$ can be usefully substituted for $S$ in model computations of total magnetic intensity.

The wet bulk density, $W$, (Table 3) is also a computed quantity. It is calculated by the expression:

$$
W=D+\frac{P}{100}
$$

where $D$ is the dry bulk density and $P$ is the percent porosity. This quantity may be of more value than dry bulk density if one is concerned about rock strata beneath the water table. In southern Arizona the water table can be from a hundred meters to a kilometer or more below the valley floors.

The more magnetic rock suites (table 1) are the basalts, andesites, and volcaniclastic rocks (S about 104 to $119 \times 10^{-4} \mathrm{SI}$ ), along with the metamorphic rocks (S about $80 \times 10^{-4}$ SI for schists and $135 \times 10^{-4}$ SI for gneisses). Quartz diorite also shows quite high susceptibility (about $134 \times 10^{-4} \mathrm{SI}$ ) as does granite (about $92 \times 10^{-4} \mathrm{SI}$ ). The value for quartz diorite is open to query because there are only 4 samples contributing to the mean. Mineralized rock in the porphyry copper deposits of the southwest are largely associated with granodiorite and quartz monzonite (Creasy, 1966, Stringham, 1966) and in line with Brant's observation (1966) these associated rocks show relatively moderate susceptibility (about 11 to $31 \times 10^{-4} \mathrm{SI}$ ). The aphanatic-porphyritic equivalents of these associated rocks show susceptibilities of similar or lower values $\left(0.30\right.$ and $\left.38 \times 10^{-4} \mathrm{SI}\right)$ for quartz latite and rhyodacite respectively.

The aphanitic igneous rocks generally have lower magnetization than their granitoid equivalents. The apparent exception is the granodiorite-rhyodacite pair, however there are only 4 samples available for the rhyodacite rocks. Although there were too few samples of the porphyries in each rock suite to list them separately, the porphyry rocks showed lower susceptibilities than the non-porphyries by factors of about 0.05 to 0.5 . For instance, of the 19 samples of the dacite-dacite porphyry group, the 13 dacite rocks had $\mathrm{S}$ of $6.00 \times 10^{-4}$ SI compared to the 6 dacite porphyry rocks with $\mathrm{S}$ of $3.07 \times 10^{-4} \mathrm{SI}$; the 2 latite rocks had $\mathrm{S}$ of $102 . \times 10^{-4} \mathrm{SI}$ compared to 5.41 $\mathrm{x} 10^{-4} \mathrm{SI}$ for the 3 latite porphyry rocks.

The high susceptibility for limestone (about $36 \times 10^{-4} \mathrm{SI}$ ) is related to relatively high detrital content. Most of the limestones sampled were dark grey to black and finely crystalline.

The present data indicate that remanent magnetization on the average accounts for over 80-percent of the rock magnetization for the gneiss, basalt, 
dacite, rhyodacite and rhyolite suites, and for more than $20 \%$ of the rock magnetization in all other igneous and metamorphic rock suites studied except for diorite-granodiorite (3-percent) and granite (5-percent). There are no data for the latite and quartz latite rock suites or for the limestone and marble suites. It is pointed out that remanent magnetization measurements were made on fewer samples than were susceptibility measurements. Those mean values shown that are based on less than 11 samples are considered tentative. This is true for all quantities in the data tables.

The densest rock suite (table 3 ) is schist $\left(2.82 \times 10^{3} \mathrm{~kg} / \mathrm{m}^{3}\right.$ ). Gneisses, along with the granitoid igneous rocks have densities whose means cluster between 2.59 and $2.66 \times 10^{3} \mathrm{~kg} / \mathrm{m}^{3}$. The indurated sedimentary rocks fall within the density range 2.64 to $2.70 \times 10^{3} \mathrm{~kg} / \mathrm{m}^{3}$. The volcaniclastic rocks show densities of $2.72 \times 10^{3} \mathrm{~kg} / \mathrm{m}^{3}$ and are more similar in density to the indurated sedimentary rocks than to the aphanitic-porphyritic igneous rocks. The relative high porosities of the volcaniclastic and aphanitc-porphyritic rocks ( 8 to $16 \%$ ) account in part for their densities being lower than those of the granitoid igneous rock suites ( 2 to $6 \%$ porosities).

It is of interest that the dry bulk densities of basalt $\left(2.54 \mathrm{x} 10^{3}\right.$ $\left.\mathrm{kg} / \mathrm{m}^{3}\right)$, andesite $\left(2.65 \times 10^{3} \mathrm{~kg} / \mathrm{m}^{3}\right)$ and rhyolite $\left(2.51 \mathrm{x} 10^{3} \mathrm{~kg} / \mathrm{m}^{3}\right)$ as reported by Johnson and O1hoeft (1983) are higher by .09 to .35 $\mathrm{x} 10^{3} \mathrm{~kg} / \mathrm{m}^{3}$ than the densities reported here (table 3). The data in Johnson and 01hoeft's report come largely from measurements on a world-wide distribution of rocks compiled by Washington (1917).

\section{SUMMARY}

Petrophysical measurements on rock samples from southwest Arizona are tabulated in appendix $B$ and are statistically summarized according to major rock types in the tables 1, 2, and 3 of this report. The data are further condensed in table 4. The granitoid igneous and metamorphic rocks (A) and indurated sedimentary and volcaniclastic rocks (D) have similar densities, typical of the usual value used to reduce gravity data $\left(2.67 \times 10^{3} \mathrm{~kg} / \mathrm{m}^{3}\right)$. The granitoid igneous and metamorphic rocks (A) contrast to the more dense schists (B) and the less dense, higher porosity, aphanitic-porphyritic igneous rocks $(C)$. The four rock groups shown on table 3 are sub-divided into more specific rock types that have differing magnetic susceptibility and apparent susceptibility. The apparent magnetic susceptibility is a measure of the relative importance of remanent magnetization to induced magnetization, but the maximum value of this parameter in interpretation can only be realized by knowing the direction of remanent magnetization which was not determined in the present work. Gneiss (A1) and quartz diorite (A2) are the most magnetic rock suites in the present data, followed by the volcaniclastic (D1) and basalt-andesite rock suites ( $C 1)$. Remanent magnetization is indicated to be important in a11 these except the quartz diorite suite (A2). Schist (B) is also relatively magnetic and its remanent magnetization is of moderate importance. The rock suites most commonly associated with mineralized igneous rock ( $\mathrm{A} 3$ and $\mathrm{C} 2$ ) are indicated to be less magnetic than the gneiss (A1) and quartz diorite (A2) granitoid rock suites and the basalt-andesite (C1) and volcaniclastic (D2) rock suites. Tab1e 3 shows the rocks of suite C2 to be less magnetic but with relatively more important remanent magnetization than their granitoid equivalents (A3). Indurated sedimentary rocks (D2) can have magnetization equivalent to the less magnetic of the igneous rocks. 
Table 4 -- Condensed summary of average magnetic and density properties for rock-sample measurements in southwest Arizona. The values of magnetic susceptibility in parenthesis are from the subset of data that was used to calculate the apparent susceptibility. Values queried are based on less than 11 samples.

\begin{tabular}{|c|c|c|c|c|c|}
\hline Rock Group & \multicolumn{2}{|c|}{$\begin{array}{l}\text { Magnetic } \\
\text { Susceptjbility } \\
\text { SI } \times 10^{4}\end{array}$} & $\begin{array}{l}\text { Apparent } \\
\text { Suscept } \frac{1}{1} \text { bility } \\
\text { SI } \times 10^{4}\end{array}$ & $\begin{array}{l}\text { Dry Bulk } \\
\text { Density } \\
\mathrm{kg} / \mathrm{m}^{3} \times 10^{-3}\end{array}$ & $\begin{array}{l}\text { Volume } \\
\text { percent } \\
\text { porosity }\end{array}$ \\
\hline $\begin{array}{l}\text { A-granitoid igneous- } \\
\text { metamorphic rock }\end{array}$ & & & & $2.59-2.66$ & $2-6 \%$ \\
\hline $\begin{aligned} \text { A1 - } & \text { gneiss } \\
\text { A2 - } & \text { quartz diorite } \\
\text { A3 - } & \text { granite-diorite- } \\
& \text { granodiorite- } \\
& \text { quartz monzonite }\end{aligned}$ & $\begin{array}{l}135 \\
134 ?\end{array}$ & $\begin{array}{l}(46) ? \\
(134) ?\end{array}$ & $\begin{array}{l}371 \\
212 ? \\
20-81\end{array}$ & & \\
\hline $\mathrm{B}-\mathrm{sch}$ ist & 80 & (49)? & $105 ?$ & 2.82 & $2 \%$ \\
\hline $\begin{array}{l}\text { C-aphanitic-porphyritic } \\
\text { igneous rock }\end{array}$ & & & & $2.27-2.56$ & $8-16 \%$ \\
\hline 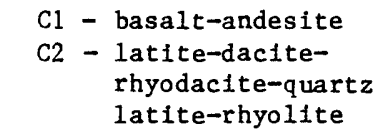 & $\begin{array}{l}104-109 \\
0.30-38\end{array}$ & $(5.0-38)$ & $\begin{array}{l}98-220 \\
13-98\end{array}$ & & \\
\hline $\begin{array}{l}\text { D-indurated sedimentary } \\
\text { and volcaniclastic } \\
\text { rock }\end{array}$ & & & & $2.64-2.72$ & $1-10 \%$ \\
\hline $\begin{array}{l}\text { D1-volcaniclastic } \\
\text { rock } \\
\text { D2-sedimentary rock }\end{array}$ & $\begin{array}{l}119 \\
11-36\end{array}$ & $\begin{array}{l}(96) \\
(4.0) ?\end{array}$ & $\begin{array}{l}204 \\
5.69 ?\end{array}$ & & \\
\hline
\end{tabular}




\section{ACKNOWLEDGEMENTS}

Sample collecting was accomplished by the first author and Frances M. Boler. Rock coring, laboratory measurements, and data compilation were done by the second author with assistance from Jody Patton, Pam Mohr, Matthew Powers, Mark Sherrard and Dale Duncan. Laboratory facilities and equipment were provided by Gary Olhoeft, Don Watson, and Rich Reynolds.

The commanders of Luke Air Force Base and Gunnery Range, the Marine Station at Yuma, and the Yuma Army Proving Ground are thanked for support in this study. Some of the key personnel who were associated with the management of these military ranges and who provide direct and helpful liaison were Mr. Gene Cook and Mr. John Forrest (Environmental officers at Luke Air Force Range), Captain Skaggs and Major John R. Lewis (Range scheduling officers of the Luke Air Force Range). The assistance of the commanders and liaison officers at the Yuma Marine Station and the Yuma Army Proving ground is also gratefully acknowledged.

Part of the area sampled was on the Cabeza-Prieta Game Range where Mr. Rog DeRosa of the U.S. Fish and Wildlife Service was very helpful. Mr. William F. Wallace, Superintendent of the Organ Pipe National Monument and Mr. Terry Peters cooperated in work conducted on the National Monument. Mr. Addison Smith, the Mining Department Director for the Papago Tribe arranged access for our work in the Papago lands. 


\section{REFERENCES}

American Society for Testing and Materials, 1976, Standard for metric practice: Philadelphia, ASTM Publication E 380-76, 37 p.

Brant, A. A., 1966, Geophysics in the exploration for Arizona porphyry copper, in Titley, S. R. and Hicks, C. L., (editors), Geology of the porphyry copper deposits southwestern North America: Tucson, University of Arizona Press, p. 87-110.

Creasy, S. C., 1966, Hydrothermal alteration, in Titley, S. R., and Hicks, C. L. (eds.), Geology of the porphyry copper deposits southwestern North America, Tucson, University Arizona Press, p. 51-74.

Greenes, K. A., 1980, Application of the gravity method to ground-water volume determinations of alluvial basins: Tucson, University of Arizona, M.S. Thesis, $28 \mathrm{p}$.

Hargan, B. A., 1978, Regional gravity data analysis of the Papago Indian Reservation, Pima County, Arizona: Tucson, University of Arizona, M.S. Thesis, $105 \mathrm{p}$.

Hunt, G. R., Johnson, G. R., Olhoeft, G. R., Watson, D. E., and Watson, Kenneth, 1979, Initial report of the petrophysics laboratory: U.S. Geological Survey Circular 789, 74 p.

Johnson, Gordon R., and 0lhoeft, G. R., 1983, Density of rocks and minerals, in Handbook of physical properties of rocks, v. 3: CRC Press, West Palm Beach, Fla., in press.

Kohle, Katherine, Conway, Dyan, and Haxel, Gordon, 1978, Compilation geologic map of the Ajo $1^{\circ} \times 2^{\circ}$ quadrangle, Arizona: U.S. Geological Survey openfile report, scale $1: 250,000,2$ sheets.

May, B. T., 1968, Magnetic properties of rocks associated with the New Cornelia Porphyry Copper Deposit, Pima County, Arizona: Tucson, University of Arizona, Ph.D. Thesis, $159 \mathrm{p}$.

Mooney, H. M., 1953, Magnetic susceptibility measurements in Minnesota: Geophysics, v. 17, no. 3, p. 531-543.

Nagata, Takesi, 1969, Reduction of geomagnetic data and interpretation of anomalies, in Hart, P. J., (ed), The Earth's crust and upper mantle, geophysical monograph 13, Washington, D. C., American Geophysical Union, p. 391-398.

Sheriff, R. E., 1973, Encyclopedic dictionary of exploration geophysics: Tulsa, Society of Exploration Geophysics, 266 p.

Strangway, D. W., 1967, Magnetic characteristics of rocks, in Mining Geophysics, v. 2: Tulsa, Society of Exploration Geophysicists, p. 454473. 
Stringham, Bronson, 1966, Igneous rock types and host rocks associated with porphyry copper deposits, in Titley, S. R., and Hicks, C. L., (eds.), Geology of the porphyry copper deposits, southwestern North America: Tucson, University of Arizona Press, p. 35-40.

U.S. National Bureau of Standards, 1974, The International System of Units (SI): National Bureau of Standards Special Publication 330, 43 p.

Washington, H. S., 1917, Chemical analysis of igneous rocks: U.S. Geological Survey Professional Paper 99, 1,201 p.

Wilson, E. D., Moore, R. T., and Cooper, J. R., 1969, Geologic map of Arizona: U.S. Geological Survey, State Geologic Map Series, scale $1: 500,000,2$ sheets. 
List of aopreviations used for rock types in the data tabulation of Appendix

jlsk

and

and, lorplt

and, myrlcav

and,oron

and,prpn, calstr

and,prph, ornplad

and,oroh,prplt

and, vesc

andp

ando, flaso

o

D,pron

$D$, vesc

D, wth

$b x$

clt

congl

dac

Jac, acril-ep

aac, met

dac,orph

dac,prph,ara

dac,prph,olad

daco

aacp,bi,plad

dacp,end

dacp,plaa

daco,ordt

d10

a

$9 d$

ad, $\operatorname{chl} \mathrm{z}$

gd, for, lalt

gd, peat

an

an, dio,oi

an, g

gn, gin

1

1,oron,bi

$1 p$

is

1s, mic

is, red

nar

peg

pny

shy, tuft

gd

al, prph

al, silc

alp alaskite

anuesite

andesite, ligntly prophylitized

andesite witn nyrolitic cavities

andesite, porphyritic

andesite,porpnyritic with calcite stringers

andesite, porpnyritic with orlented oladioclase

anaesite, porpnyritic, propnylitized

andesite, vesicular

andesite-porohry

andesite, feldspatnic

basalt

basait, porphyritic

rasalt, vesicular

oasalt, weathered

oreccia

calcalutite

conalomerate

dacite

acite, altered chlorite-epidote

racite, metanorphozed

dacite, porpnyritic

dacite, porphyritic, argillaceous

dacite, ooronyritic with plagioclase pnenocrysts

dacite-porpnry

dacite-oorphry,biotite and plaqioclase phenocry dacite-porphry epodized

dacice-oorphry witn plagioclase onenocrysts

dacite-borphry,pronnylitized

diorite

aranite

granodiorite

aranodiorite,cnioritizea

Granodiorite, fine-grained, 1 ightly-altered

aranoalorite, pegmatitic

gneiss

ineiss, diorite with biotite

granite-gneiss

aneiss, quartz-monzonite

latite

latite,porphyritic with oiotite phenocrysts

latite-porphry

11 inestone

micritic ilimestone

Iinestone, rea

marble

pegmatite

inyilite

phyliticic tuft

quartz-diorite

quartz-latite, porpnyritic

quartz-latite,silicified

quartz-latite porpnry

A1 
Appenolx A, Table Al - continued

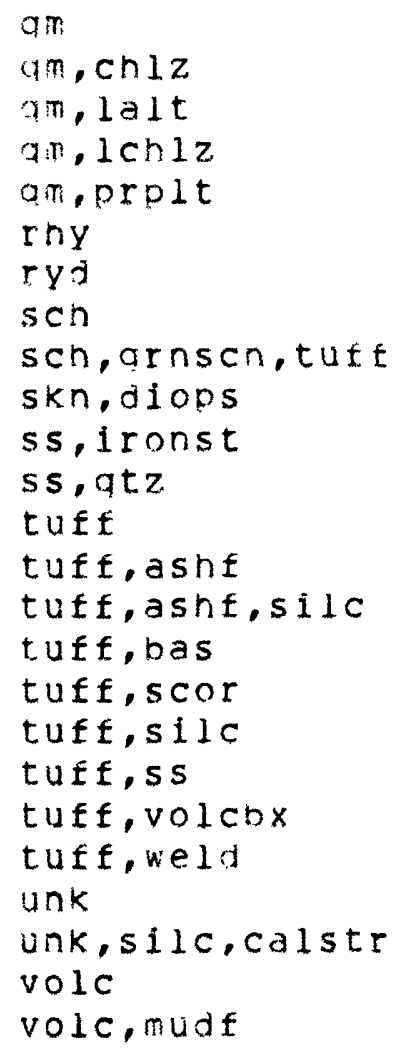

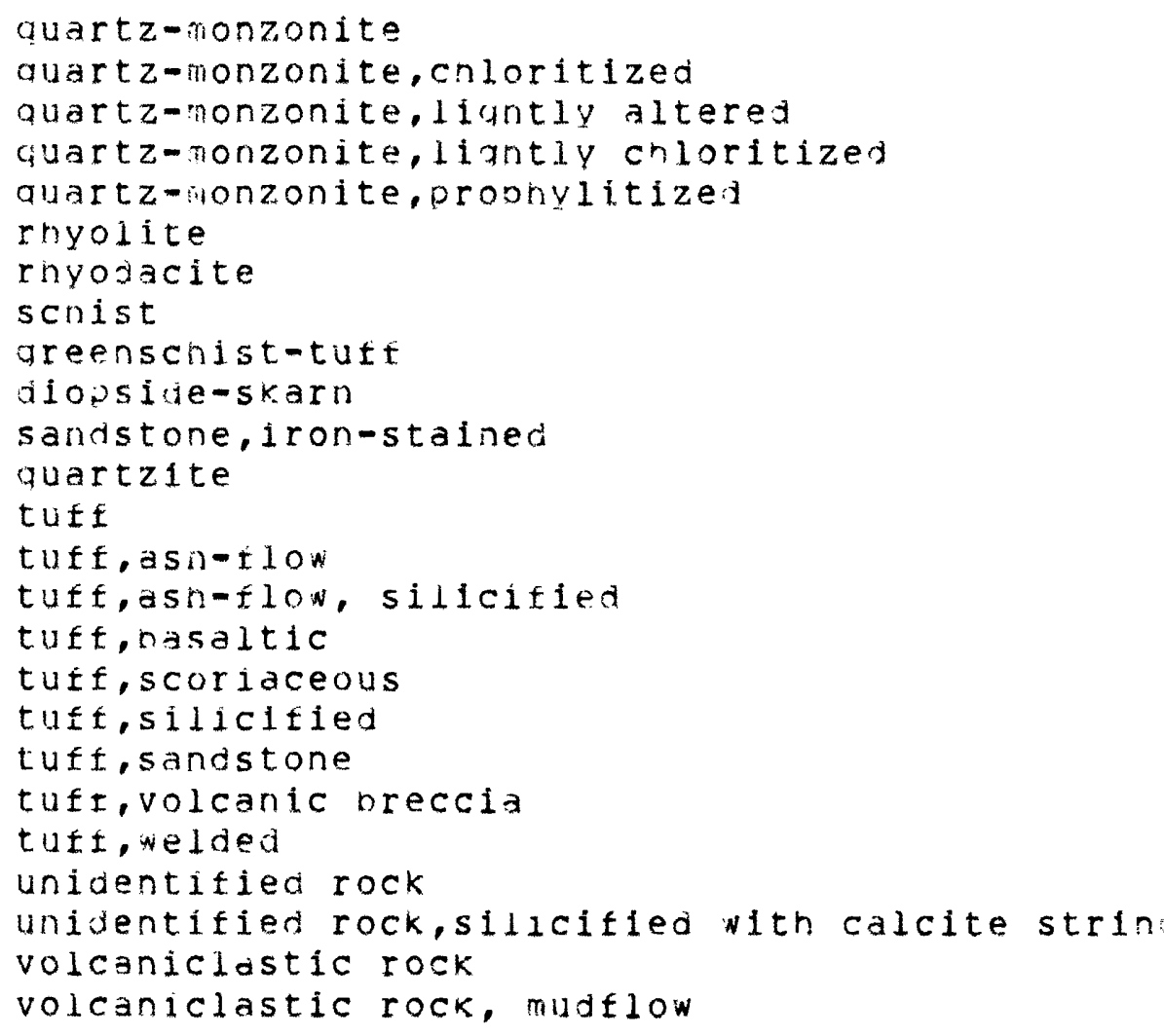




\section{APPEDinA A, TaOLe A2}

list of aboreviations used for ceofoyic ma formations in the data tabulation of apnenatix 8 .

TAP UNTTS USED FOK OATA SUUKCF 1

TAKEN FROA KUHLA, CUNAI AND UAKEL(1976)

\begin{tabular}{|c|c|}
\hline$\times 5$ & Sedimentary deposits \\
\hline 20 & Hasalt fions \\
\hline ts & Seditientary denosits \\
\hline t t $b$ & tasalt flows \\
\hline I s & Conglonerate, oreccia ano sandstone \\
\hline TVS & silicic volcanic rocks \\
\hline T 1 & Interinediate volcaric rocks \\
\hline$r b$ & Easalt fions \\
\hline Yi & Hypabyssal intrusive rocks and plugs \\
\hline l'ka & Granitic rocks: Granite to aiorite \\
\hline r Kam & Granitic rocks, accessory muscovite,garnet \\
\hline$v$ & rocks,silicis to natic \\
\hline ra & Andesite \\
\hline Mzsc & Schist, onyllite, seri-schist, ana quartzite \\
\hline yan & Gneiss \\
\hline $\mathrm{Mzg}$ & Granitic rocks \\
\hline$M 25 \mathrm{~V}$ & sedinentary rocks \\
\hline $\mathrm{oCn}$ & Gneiss and scoist \\
\hline $\mathrm{Cq}$ & Granitic rocks \\
\hline
\end{tabular}

duaternary

viaternary

rertiary and Quaternary

Tertiary and guaternary

Tertiary

Tertiary

rertiary

rertiary

rertiary

lertiary and cretaceous

Tertiary and cretaceous

cretaceous

cretaceous

viesozoic

Mesozolc

mesozolo

nesozoic

vrecamorian

precambrian

MAP UNITS USEU FOK DATA SOURCF 2

KOHLE, CONHAY, HAXEL (191\%)

\begin{tabular}{|c|c|c|}
\hline QS & seaimentary deposits & Duaternary \\
\hline tb & Basalt tlows & rertiary and waternary \\
\hline$T b$ & Basalt flows & rertiary \\
\hline $\mathfrak{l} \vee \mathfrak{i}$ & Intermediate volcanic rocks & Tertiary \\
\hline TKq & Granitic rocks,granite to jiorite & Cretaceous \\
\hline I Kggm & cranitic rocks, accessory ruscovite or garnet & Cretaceous \\
\hline KSC & Schist, phylite, semi-schist, and puartzite & Hesozoic \\
\hline 129 & Granitic rocks, granitic to iloritiç & esozolc \\
\hline $\mathrm{ZSV}$ & Sedinentary rocks & nesozoic \\
\hline
\end{tabular}

unk unknown

HLSOH, MUOKE AML (WHER (1969)

is sedimentary deposits

to sasalt flows

ivs silicic volcanic rocks

lvi Intermediate volcanic rocks

jkr volcaric rocks, rhyolitic

rkg Granite, quartz monzonite, granooiorite

TKsc scnist and onyllite

$1 \mathrm{kgn}$ Gine1s

xa Andesite flows and tuffs

Duaternary
Quaternary
certiary
Sertiary
Cretaceous and Tertiary
Cretaceous and Tertiary
Cretaceous and Tertiary
Cretaceous and rertiary
Cretaceous




$$
\text { 4PPENDIX A, Tade AL - continued }
$$

MAP UNITS USED FOR DATA SUURCE 3

FROM B.T. A AY (196\%)

rlf locomotive fanglomerate

rcm Cornelia wuartz nonzonite

red Cornelia wuartz wonzonite, xioritic border

Tertiary

rertiary

Tertiary

r.cv Concentrator volcanics

occa Cardian uneiss 
List of aooreviations usea to indicate sample station location and orefixing the sample iaentification numer in aboendix 9 . In most cases the location reters to the 1 b-ininute quadrangle in soutnern Arizona.

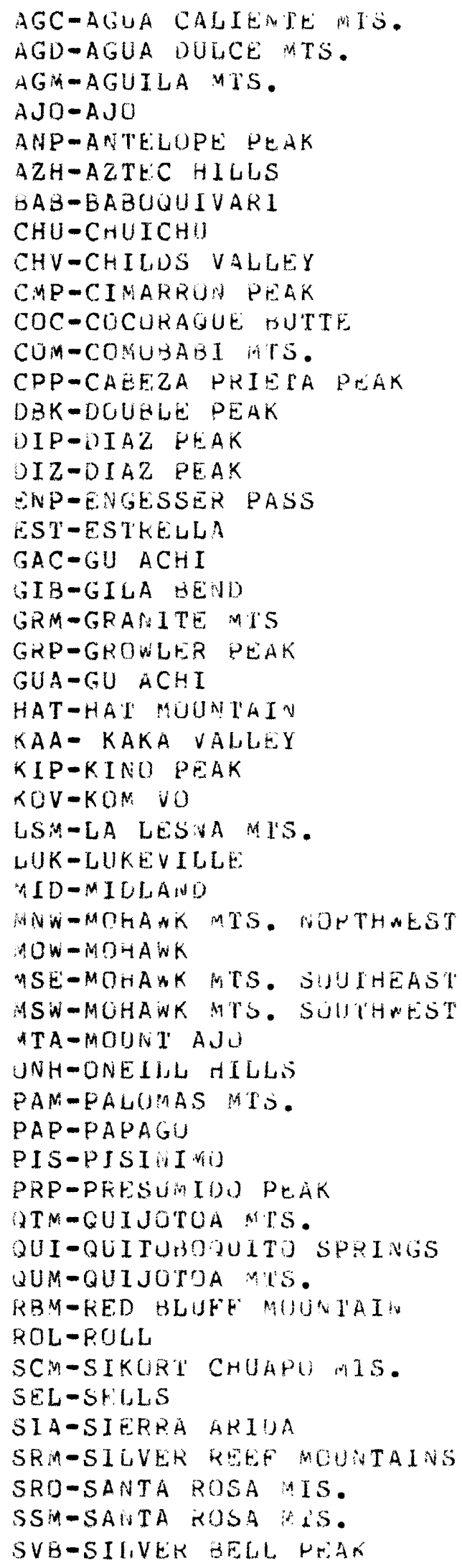




\section{APPENBLX 4, Table is 3 - continued}

THE-THEBA

TUM-TIJEE MTS.

VAH-VACA HILLS

VAM-VAMORI

VEM-VEKOL ATS.

VHLIV VACA HILLS

VKM-VEKOL WS.

NSE-MELLTUU SE 


\section{APPENDIX B}

Tabulation of rock specimen locations and petrophysical measurements. The tabulation is sorted alphabetically first by rock-type abbreviation and second by physiographic locality.

Sample: Identification code for the sampling station. The first three letters abbreviate the quadrangle name in which the sample was acquired.

Physiographic location: The name of the prominent physiographic feature in the vicinity of each sample station.

Map Unit: Abbreviation of the geologic map unit on which the sample was acquired, see Appendix A, table A2.

Rock Type: Abbreviation for the name and description of each sample, see Appendix A, table Al.

Magn. Suscept.: Measured magnetic susceptibility in units of $10^{-4} \mathrm{SI} \cdot 1$

Reman. Magn: Measured remanent magnetization in units of $10^{-2} \mathrm{amp} / \mathrm{m}$ (SI). 1

Dry Dens.: Measured dry bulk density in units of $10^{-3} \times \mathrm{kg} / \mathrm{m}^{3} \cdot 1$

Wet Dens.: Measured wet bulk density in units of $10^{-3} \mathrm{x} \mathrm{kg} / \mathrm{m}^{3} .1$

Poros.: Measured volume percent pore space. 1

Source Code: Code for the source of data: 1, U.S. Geological Survey, 2; University of Arizona (see Hargan, 1978); 3, May (1963).

1 A value of -1.0 indicates that measurements are not available. A value of 0.0 for magnetic susceptibility or remanent magnetization indicates that the susceptibility was lower than the resolution of measurement (a maximum value of $1.25 \times 10^{-4}$ was used in calculations of this report). 


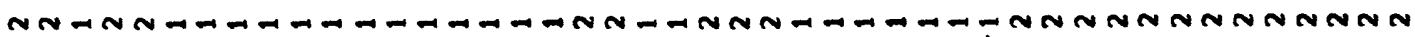

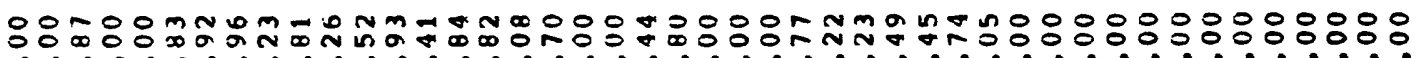

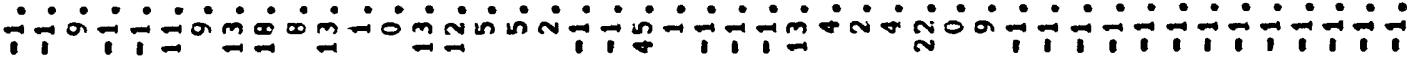

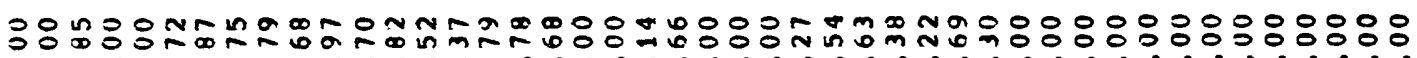

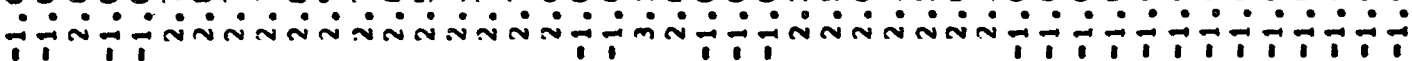

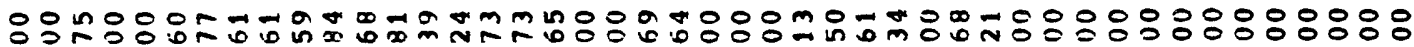
¡̈ $00000000000000=00000000000 x 000 N$ n 0000000000000

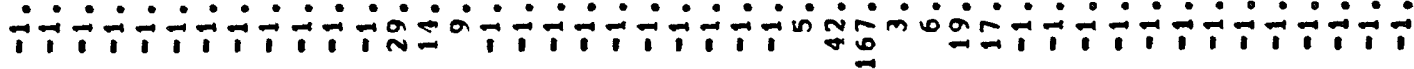
o

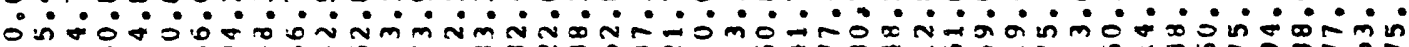

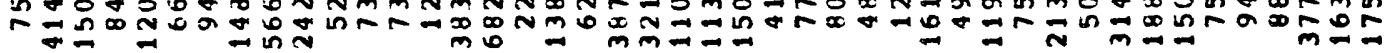

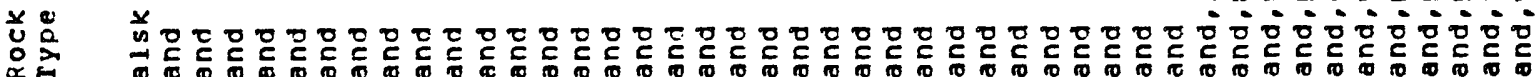

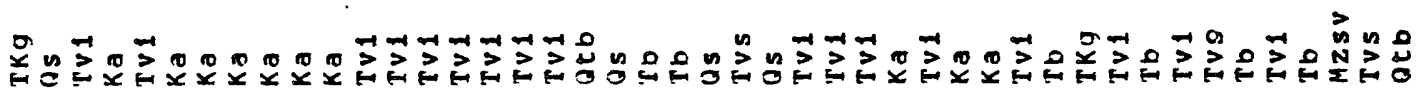

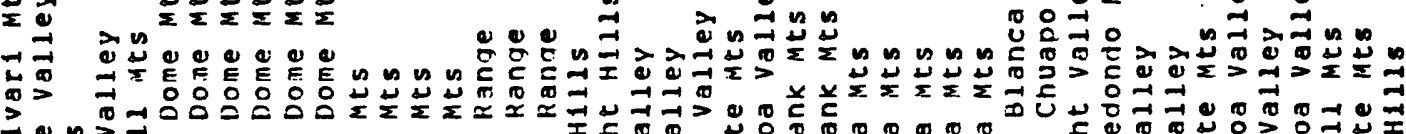

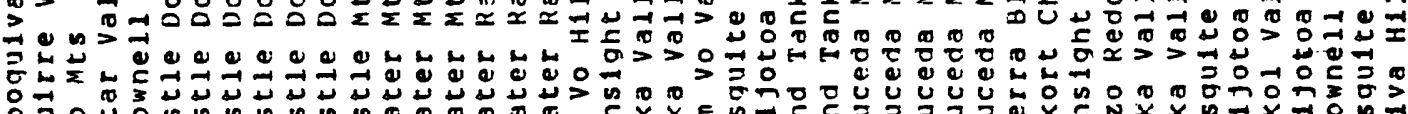

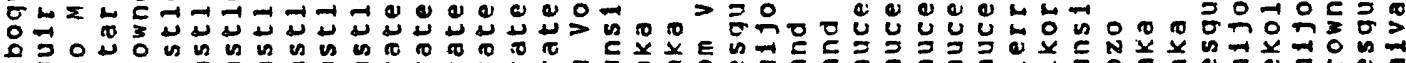

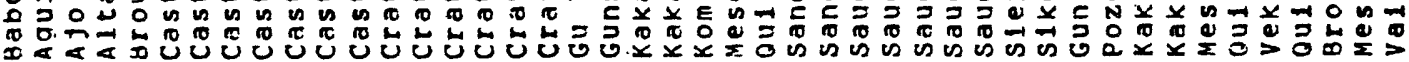

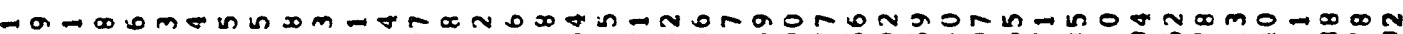

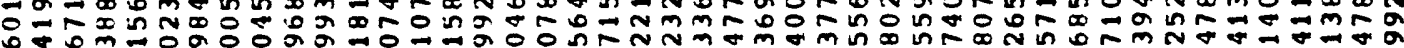

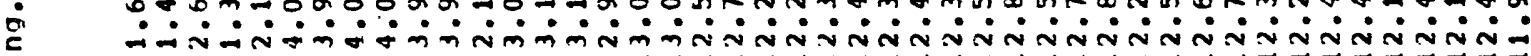

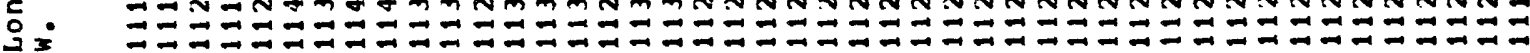

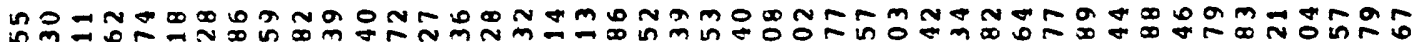

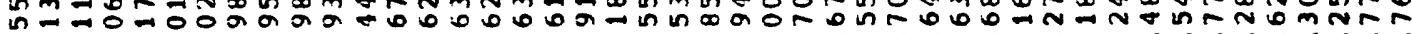

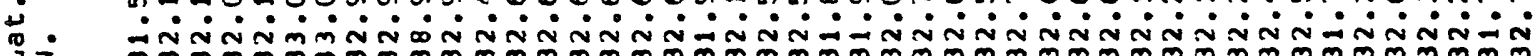

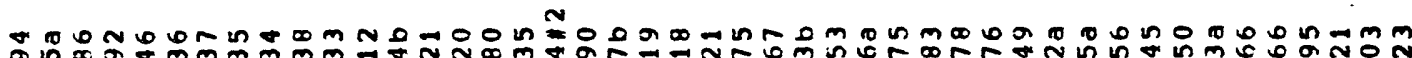

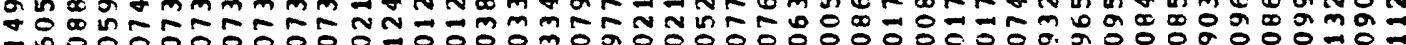

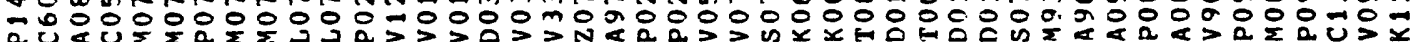

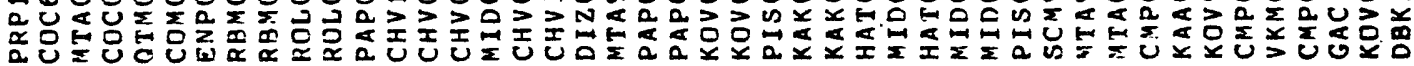


Nm-m-

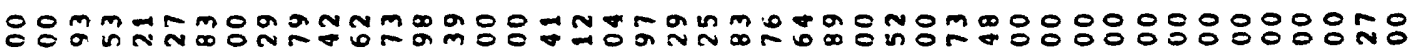
$\because-100$ in்-

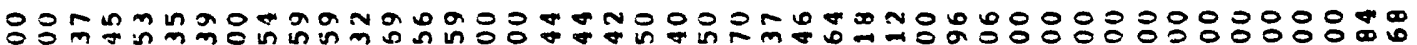

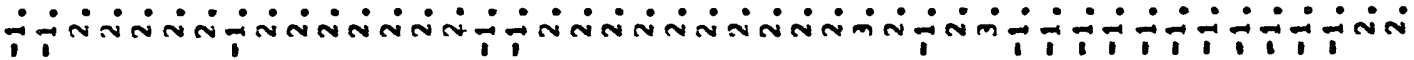

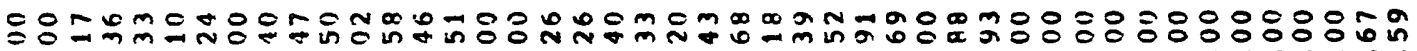

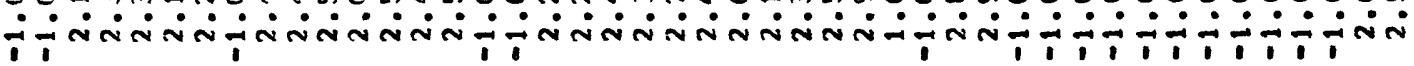

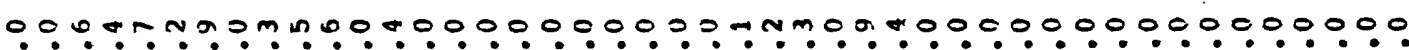

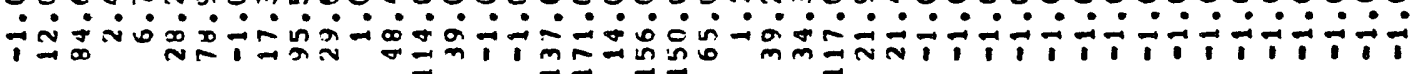
ma 0 m nn

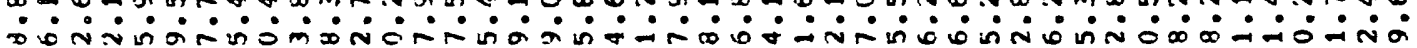

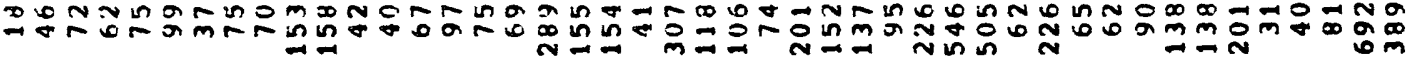

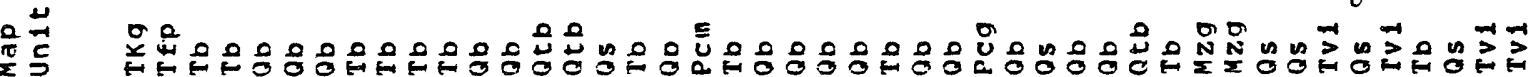

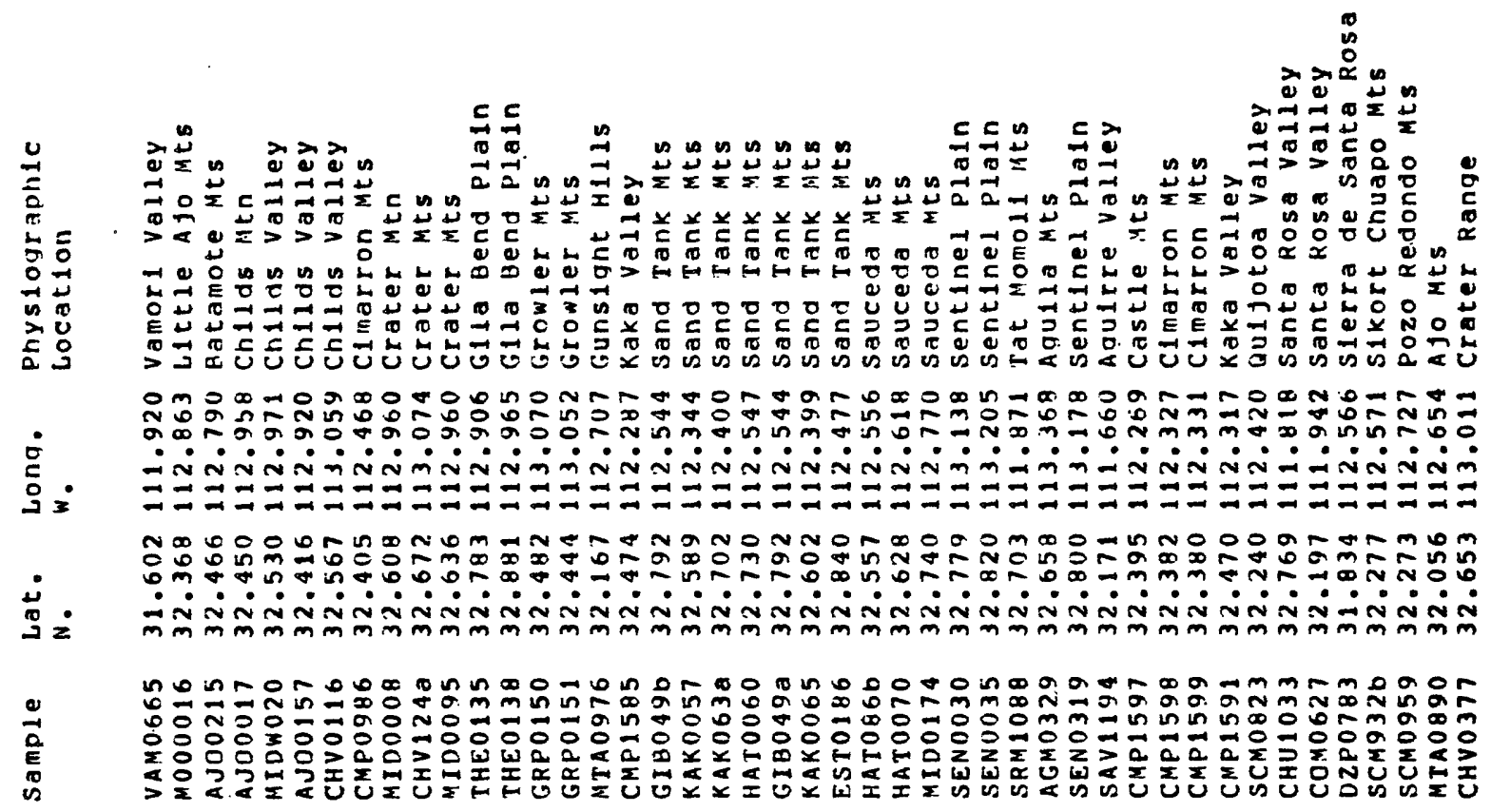




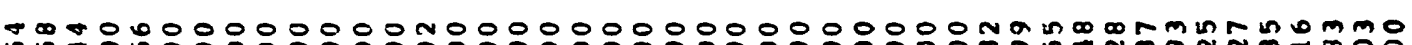
ni

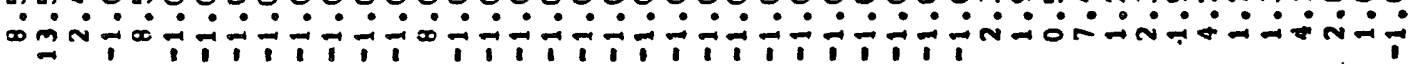

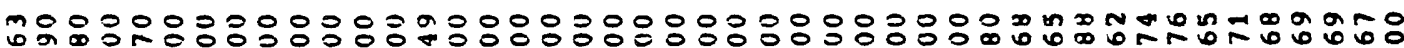

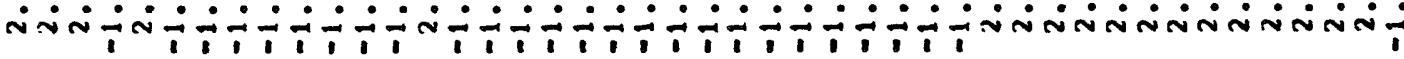

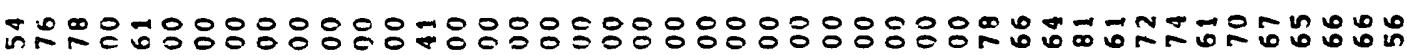

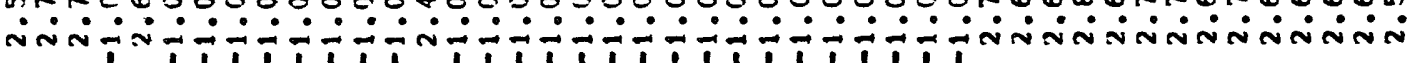
0000000000000000000000000000000000000000000000

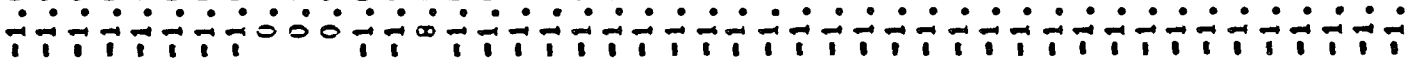

บ

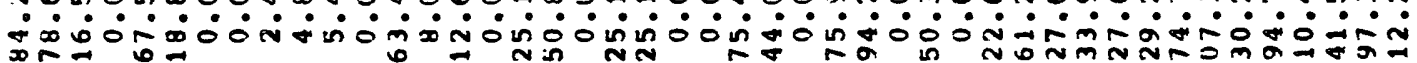

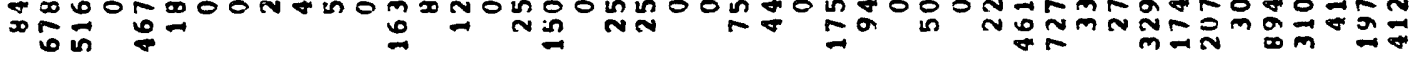

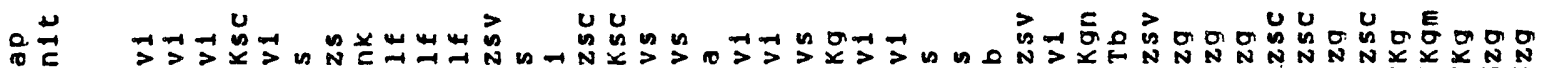

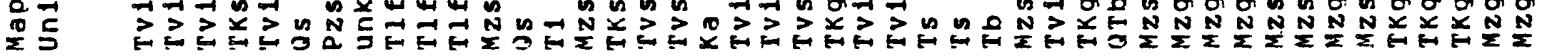

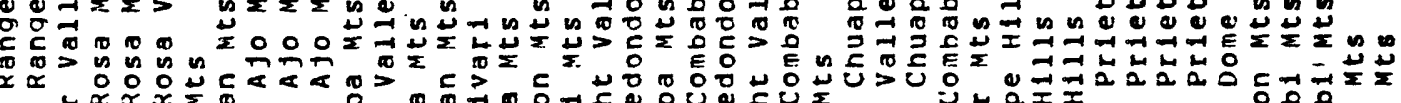

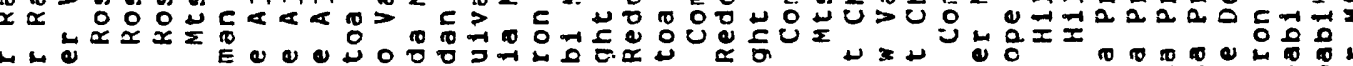
แ

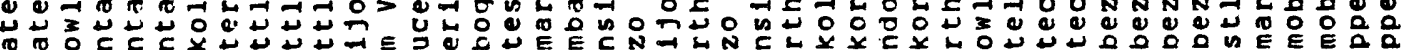

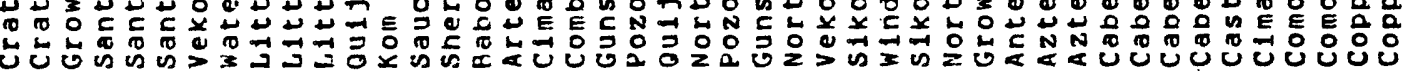
๔

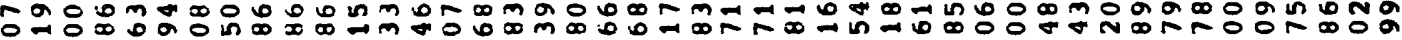

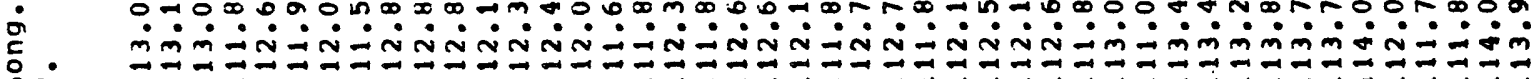

1. ㅁㅇㅛ

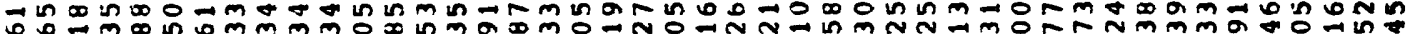
$\stackrel{\dot{0}}{3}$

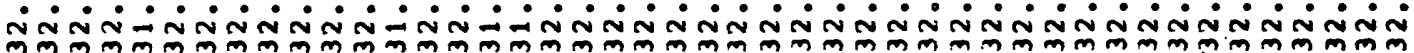

*

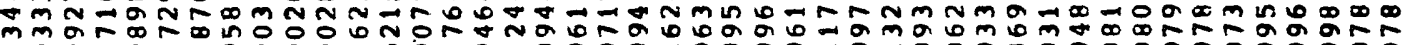

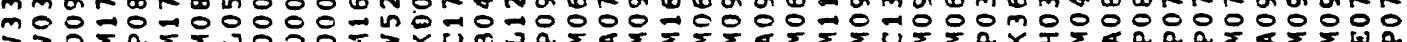

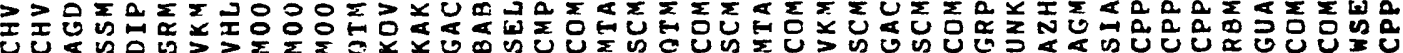




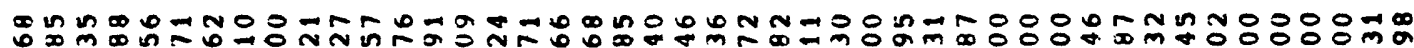

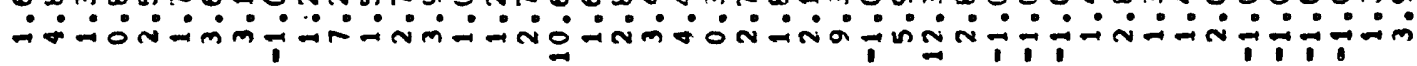

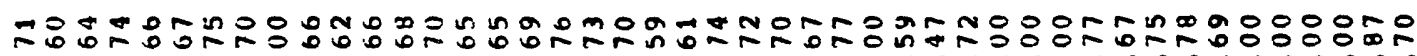

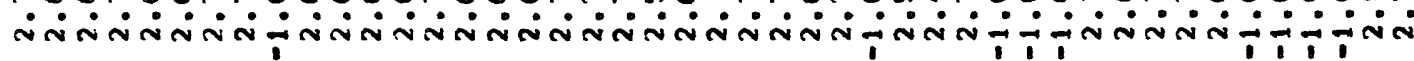

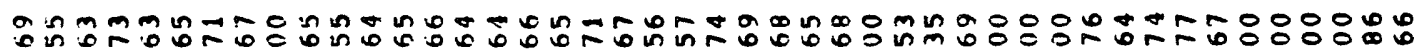

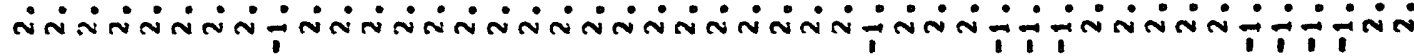
$0=00000000 m 00000000000 m 000=0-00000000000 m 0000$

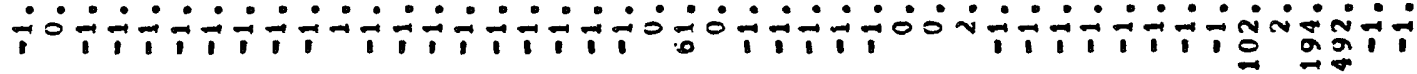

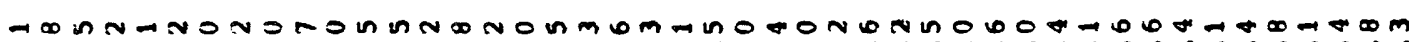

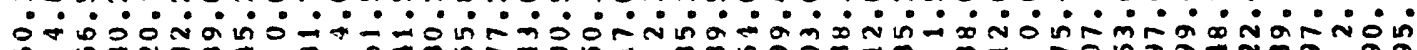

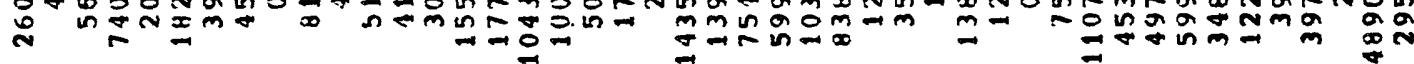

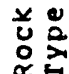
0000000000000000000000000000050 $\stackrel{2}{*}$

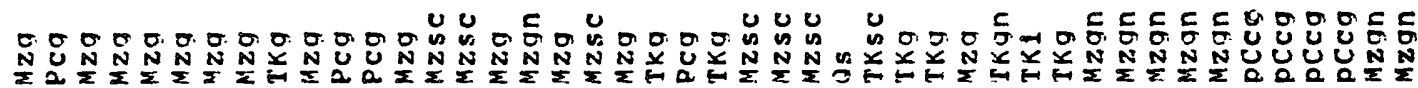

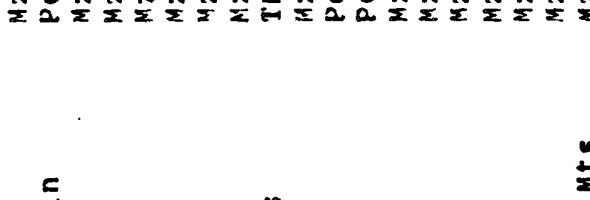

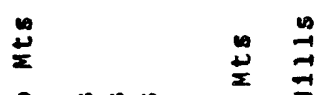

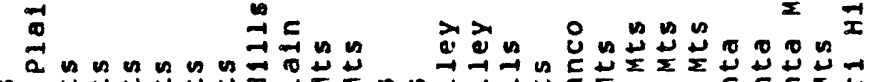

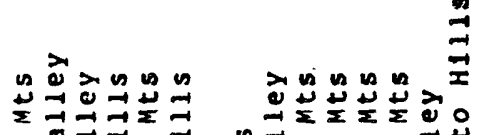

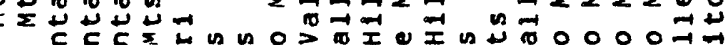

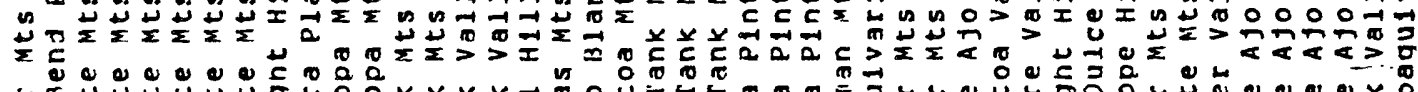

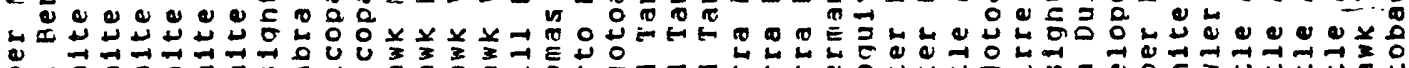

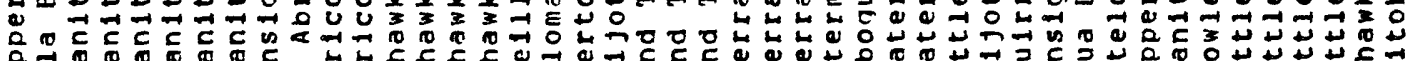

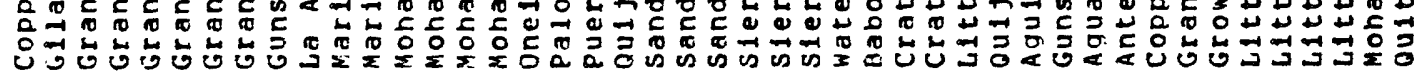

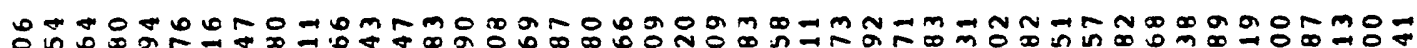

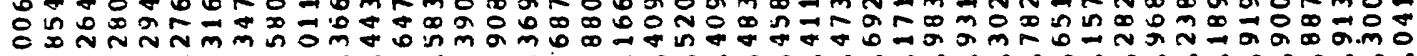

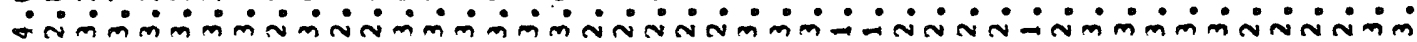

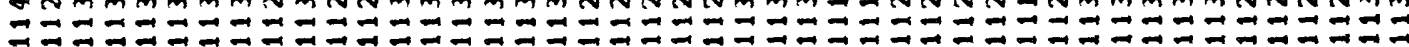

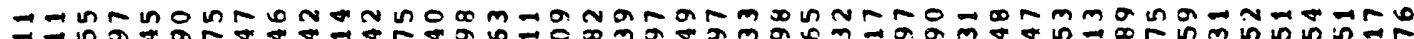

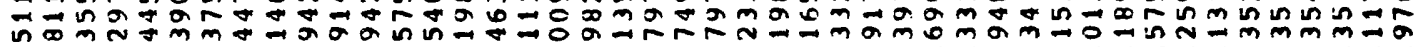
$\stackrel{\substack{s \\ \Xi}}{2}$ 섰

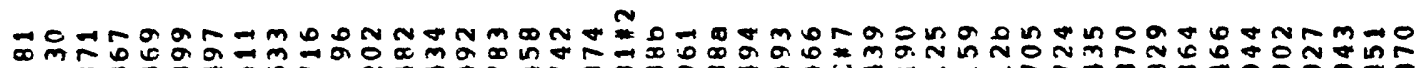

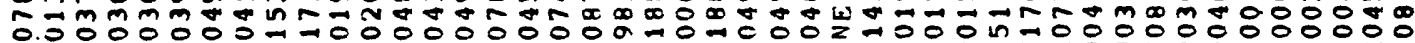

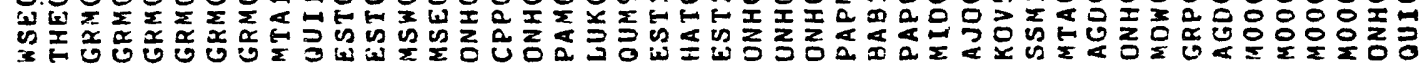


$\rightarrow \rightarrow n n-n+N$ n

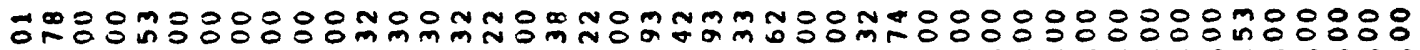

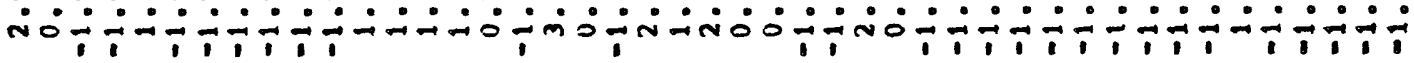

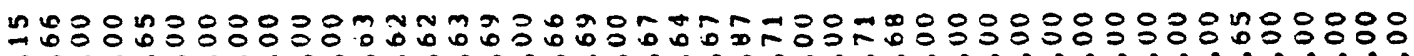
ن

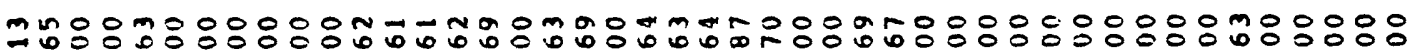

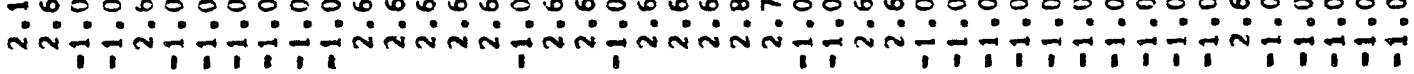
000000000000000000000000000000 rnmo000000-tman

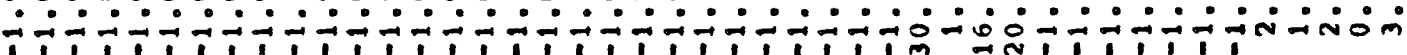

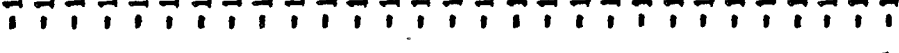

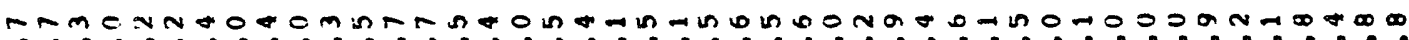

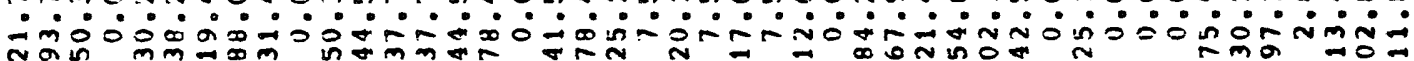

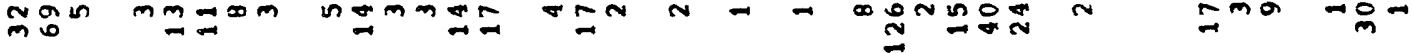

亘<smiles>COCCO</smiles>

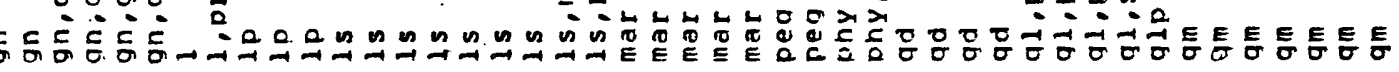
$\stackrel{2}{2} \frac{1}{5}$

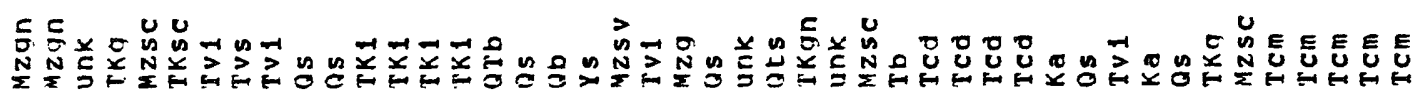

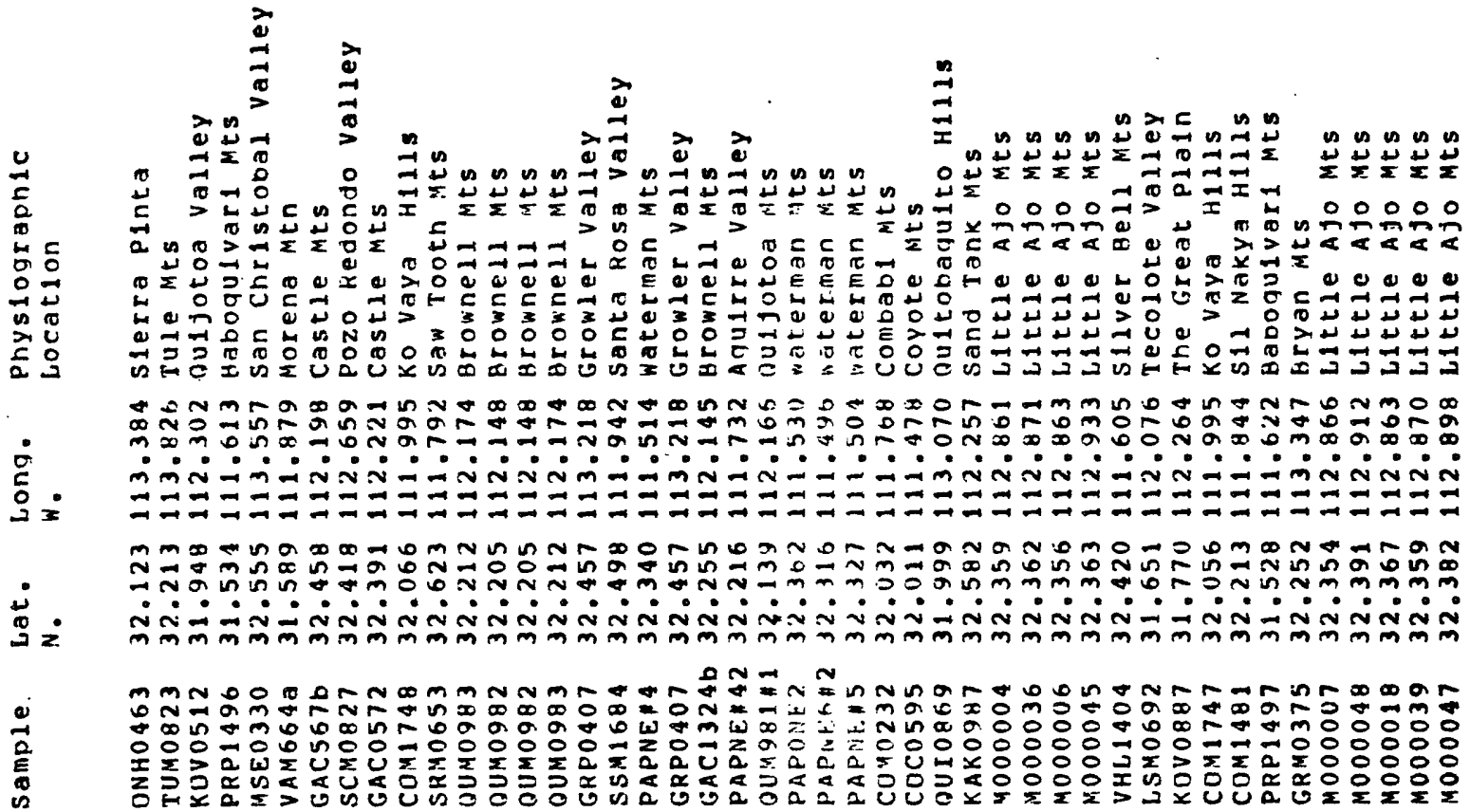


$m m m m m m m m m m n N$ N

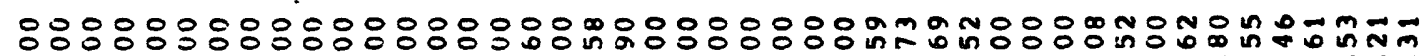

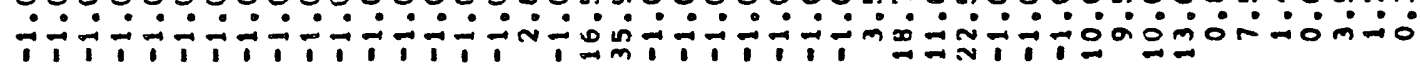

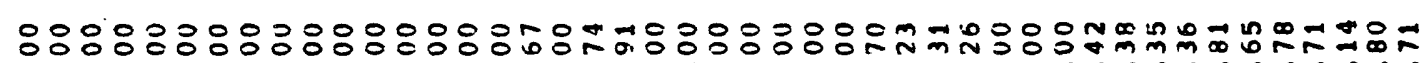

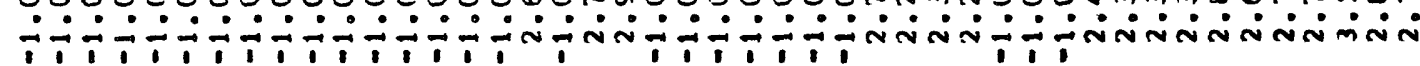

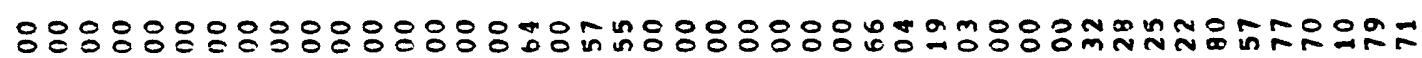

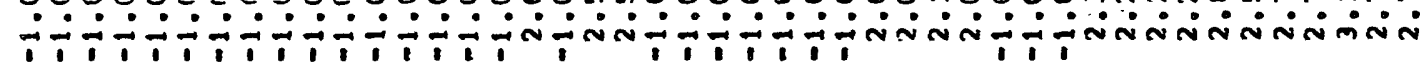

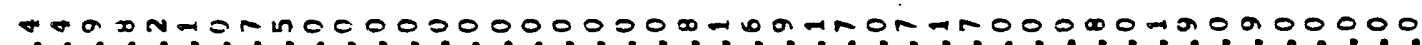

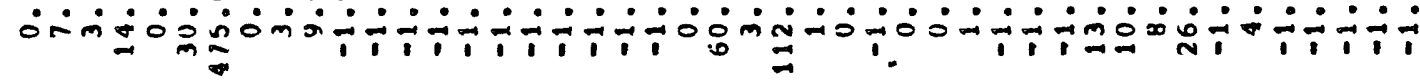

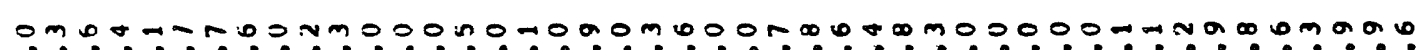

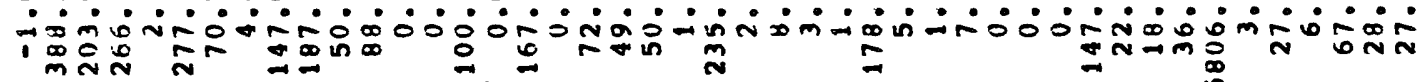

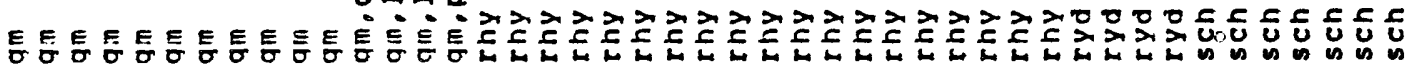
E

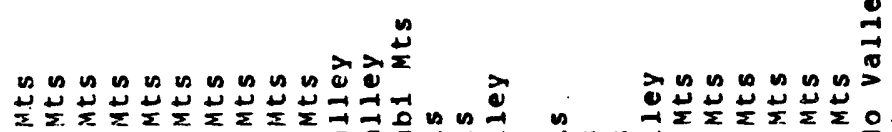

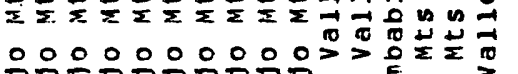

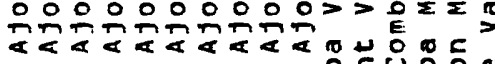
ข

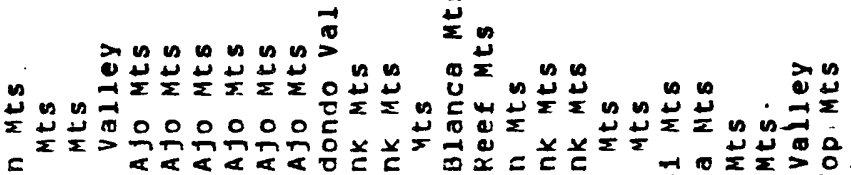

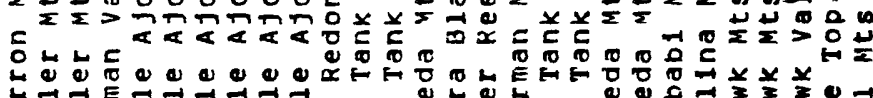

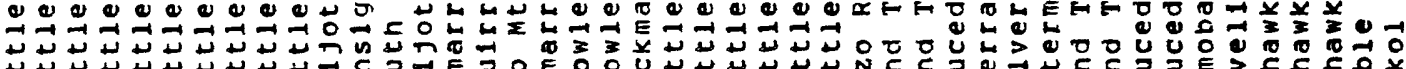

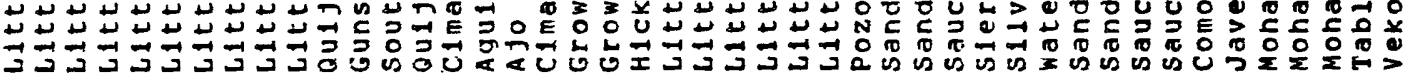

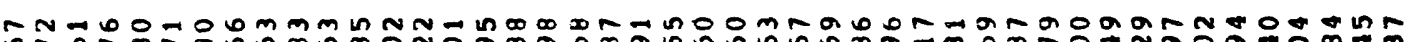

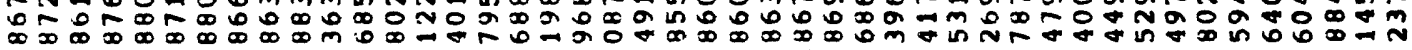

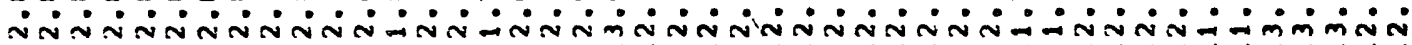

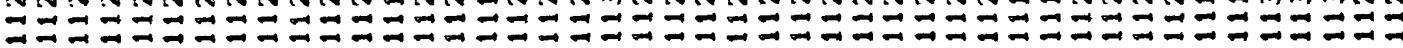
กิที่ు

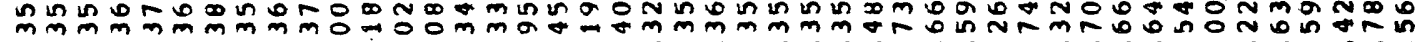
$\stackrel{0}{\$}$

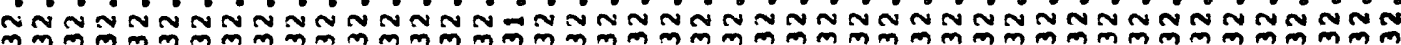

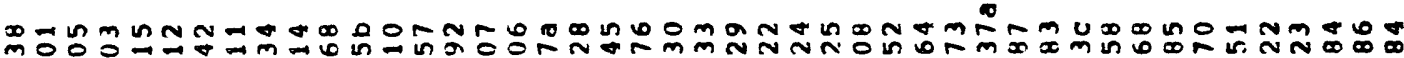

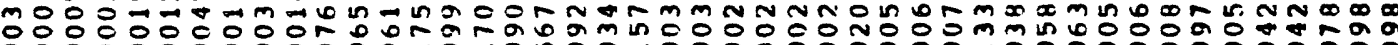

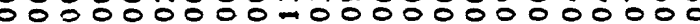

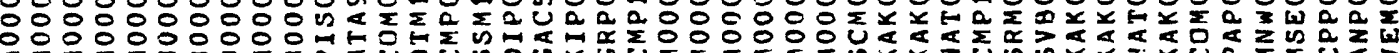




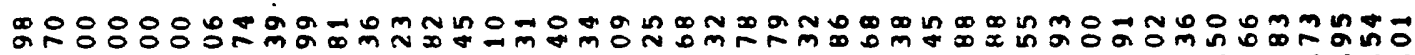
○

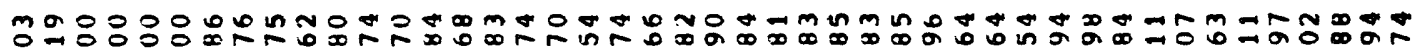

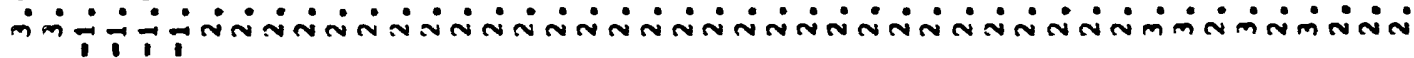

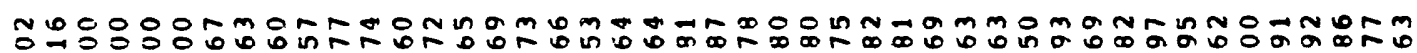

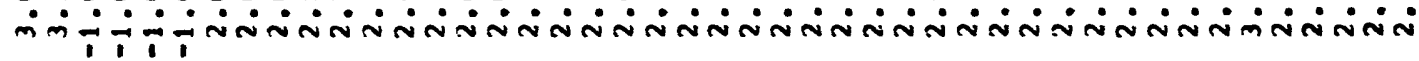

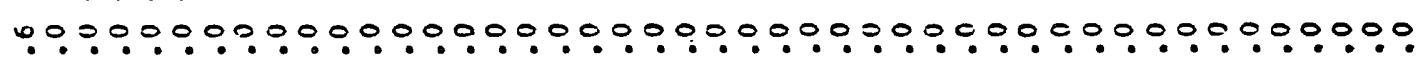
$\doteq \div \div \div \div \div \div \div \div \div \div \div \div \div \div \div \div \div \div \div \div \div \div \div \div \div \div \div \div \div \div \div \div \div \div \div \div \div \div \div \div \div \div \div$

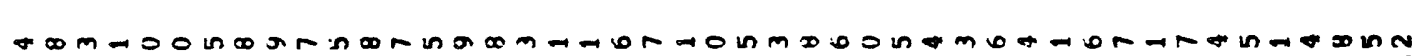

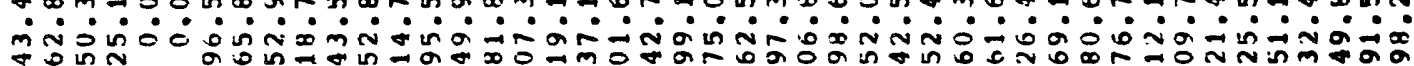

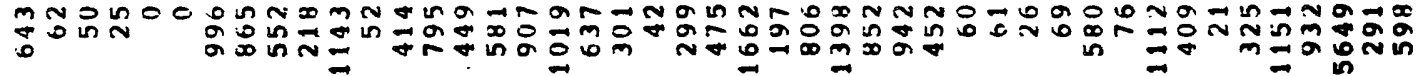

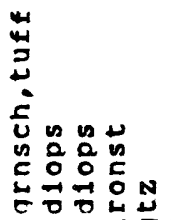

石员

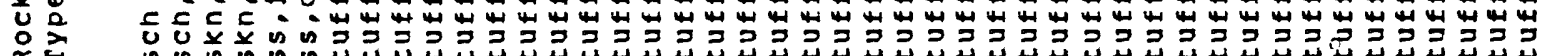

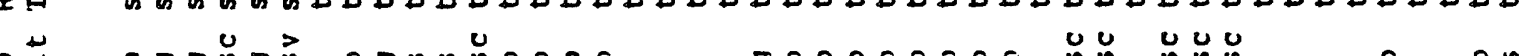
$\stackrel{2}{\frac{\pi}{5}} \underset{5}{5}$

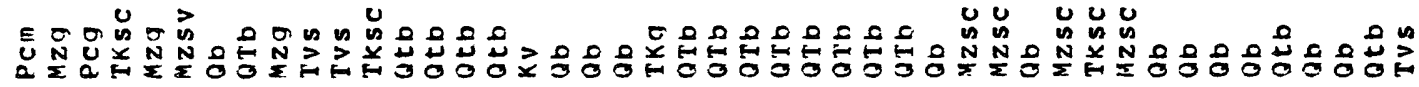

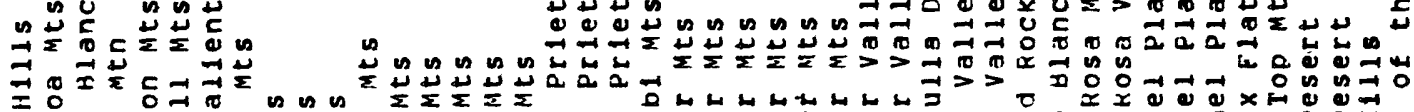

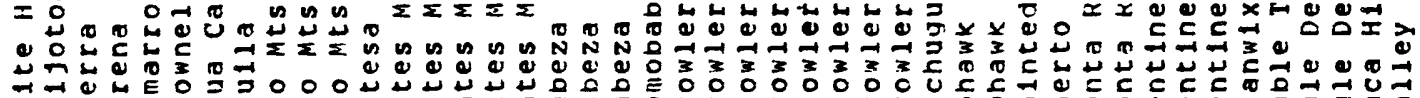

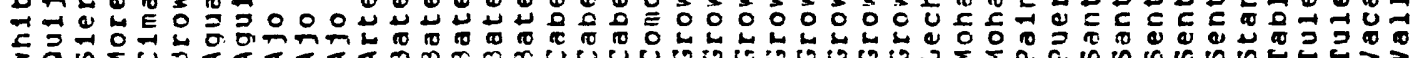

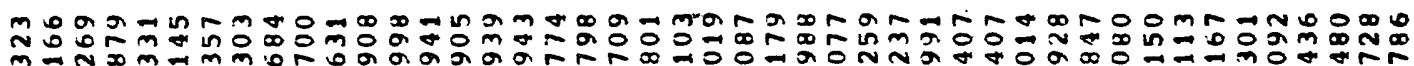

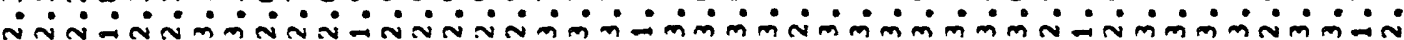

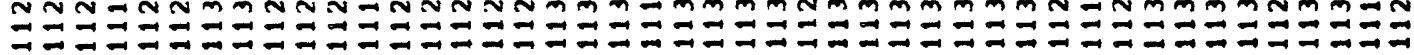

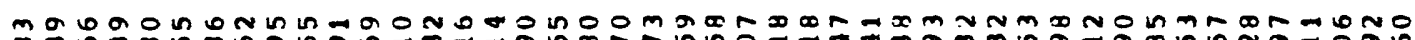

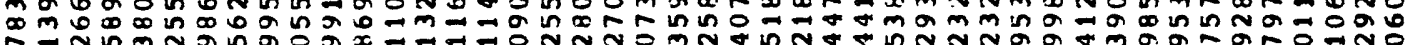
$\stackrel{\dot{0}}{9}$

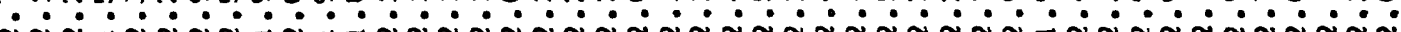

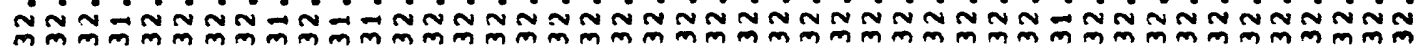

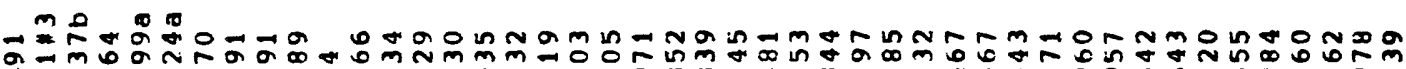

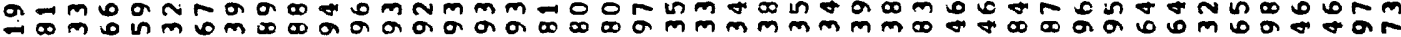

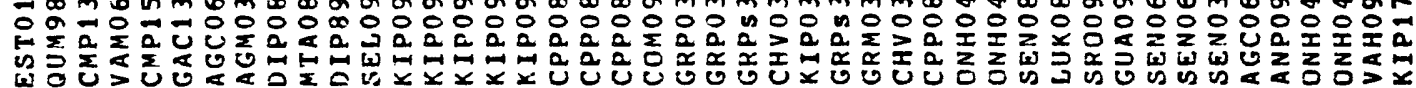




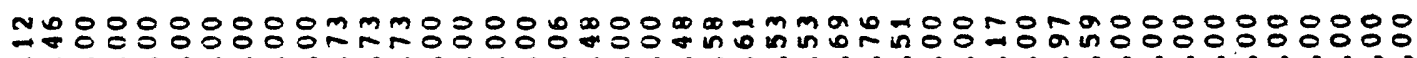

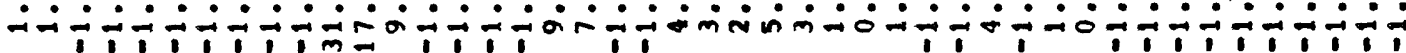

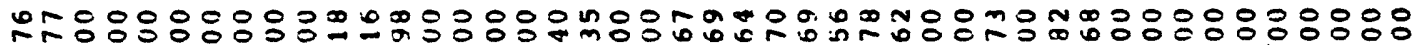
Ni

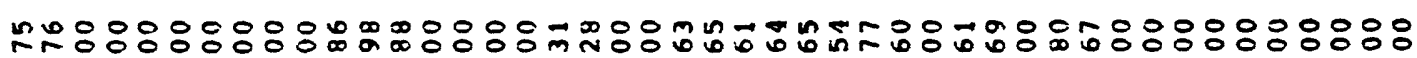

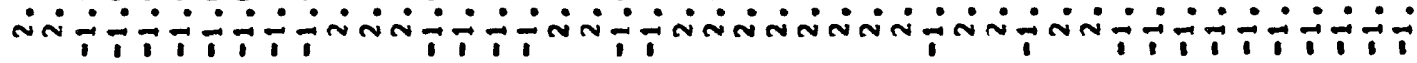
$00000000000000000 m 0000000000000000000,0 m 0 n \infty m r$

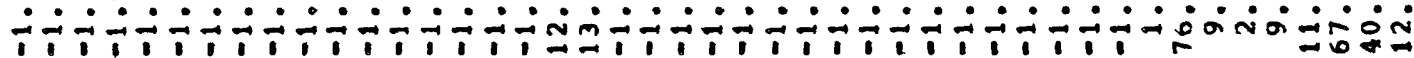

录

山世山ш山山心

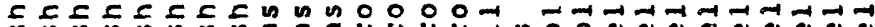

ह

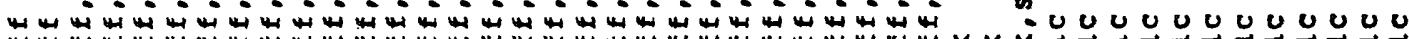

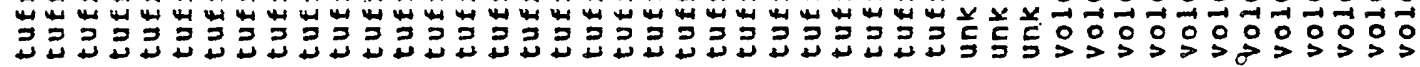

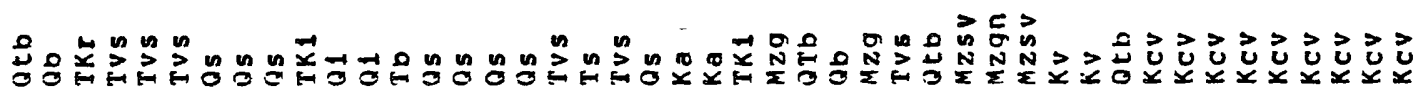

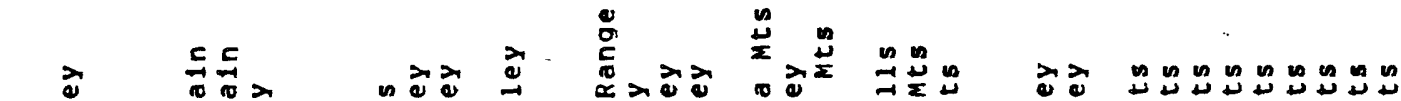

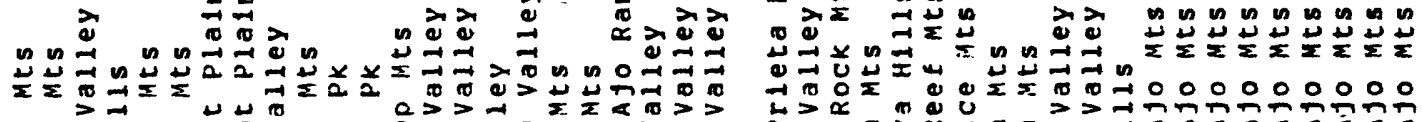
ᄃ ô 嵌

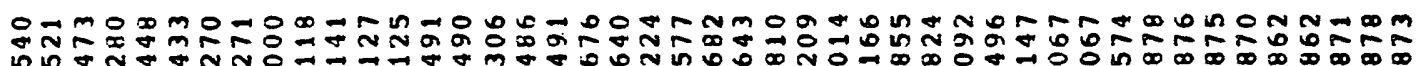

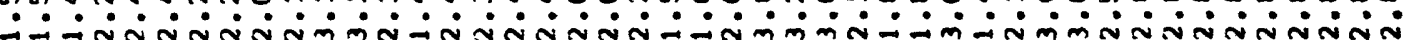

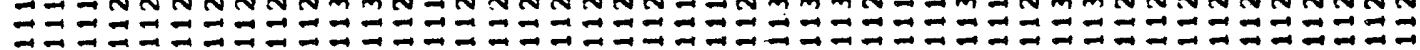

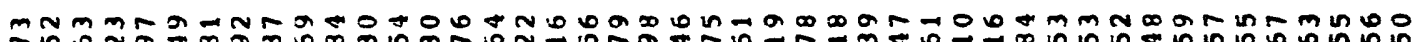

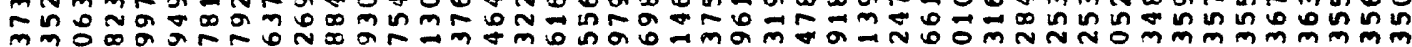

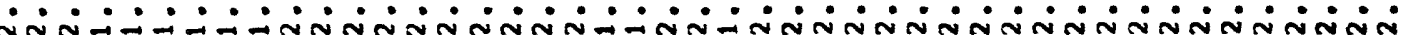

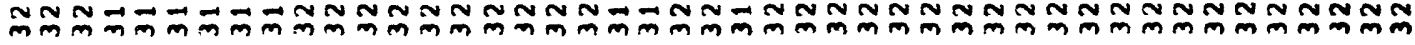
*

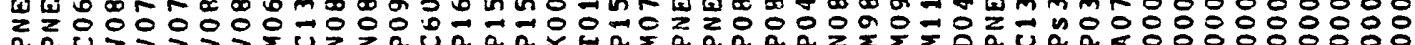

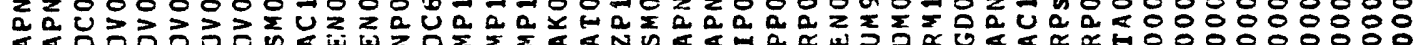

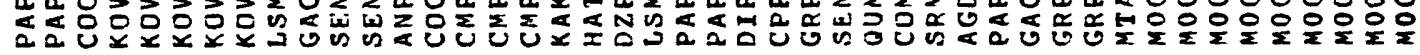




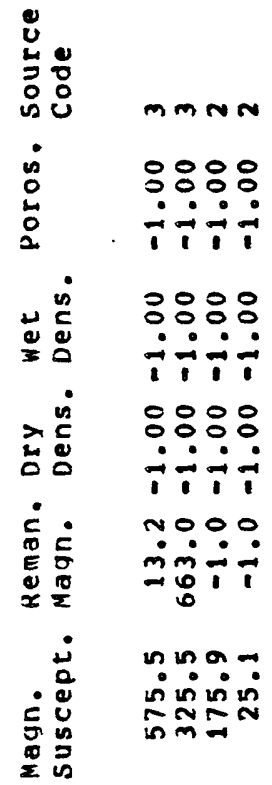

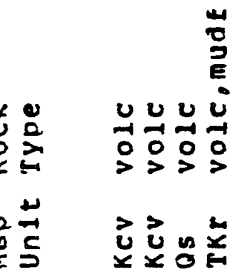

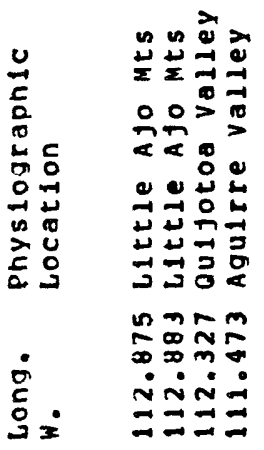

กิำ负

范

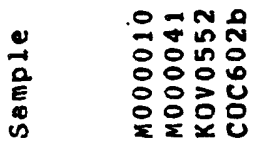


Tabulation of petrographic identification of selected rock specimens. Fiftynine samples are listed according to primary rock types. The sample location identification is listed without the three letter prefix of Appendix $B$ that identifies the area or quadrangle. Petrographic identification of commercially prepared thin sections was by Robin Bradley (USGS, Menlo Park).

Primary Rock Type and

Sample Location Identification Petrographic Identification

andesite

176

178

$124 \mathrm{~b}$

120

636

83

121

53

$86 a$

175

basalt

60

186

$124 \mathrm{~A}$

$124 \mathrm{~A}$

116

138

135

150

W20

35

151

157

65

30

17

174

57

70

$49 b$

$49 a$

8

215

$86 \mathrm{~b}$

95

$63 a$ cryptocrystalline hornblende andesite pilotaxitic hornblende andesite pilotaxitic hornblende andesite mesocratic hornblende dacitic andesite mesocratic pyroxene-amphibole andesite biotite-hornblende-pyroxene andesite pilotaxitic pyroxene-amphibole andesite hornblende andesite pyroxene basaltic andesite pyroxene-hornblende andesite

olivine basalt

olivine basalt

vesicular pilotaxitic olivine basalt

vesicular pilotaxitic olivine basalt

pyroxene-olivine basalt

vesicular olivine basalt

vesicular pyroxene-olivine basalt

vesicular pilotaxitic pyroxene basalt

vesicular pyroxene-olivine basalt

vesicular pilotaxitic pyroxene basalt

pilotaxitic pyroxene-olivine basalt

vesicular pilotaxitic olivine basalt

vesicular pilotaxitic olivine basalt

vesicular pilotaxitic olivine basalt

vesicular olivine basalt

porphyritic olivine basalt

vesicular olivine basalt

vesicular pilotaxitic olivine basalt

vesicular pilotaxitic olivine basalt

vesicular pilotaxitic olivine basalt

vesicular olivine basalt

vesicular pyroxene-olivine basalt

porphyritic olivine basalt

vesicular olivine basalt

microcrystalline olivine-pyroxene basalt 
dacite

biotite-hornblende dacite

granite

196

130

125

61

188

$188 \mathrm{a}$

granodiorite

125

190

159

rhyodacite

73

68

58

85

$63 c$

rhyolite

64

52

73

schist, gabbro, sandstone and quartzite (or tuff)

51

191

193

182

74 granite leucocratic granite

leucocratic granite

muscovite-biotite granodiorite

leucocratic biotite rhyodacite

leucocratic biotite rhyodacite

leucocratic biotite rhyodacite

biotite-hornblende rhyolite

calcite

biotite-hornblende rhyolite

sericite-biotite schist slightly foliated leucocratic biotite granite slightly lineated leucocratic hornblende-biotite

slightly cataclastic leucocratic biotite granite slightly foliated leucrocratic biotite granite

leucocratic biotite granodiorite

retrograde deuteric metamorphosed chloriteepidote-greenshist granodiorite

cryptocrystalline hornblende rhyodacite

leucocratic hornblende-biotite rhyodacite

biotite-hornblende rhyolite with extensive

amphibole-epidote-quartz-sericite greenschist

hornblende-asgirine-augite gabbro

siliceous ash-fall tuffaceous sandstone

medium-wel1-sorted subrounded quartzite

(or siliceous tuff) - poor slide 